\title{
Metal complexes with Schiff-base ligands - pyridoxal and semicarbazide-based derivatives
}

\author{
VUKADIN M. LEOVAC ${ }^{1 * \#}$ VIOLETA S. JEVTOVIĆ, ${ }^{1 \#}{ }^{\text {LJILJANA S. JOVANOVIĆ }}{ }^{1 \#}$ and \\ GORAN A. BOGDANOVIĆ ${ }^{2}$ \\ ${ }^{1}$ Department of Chemistry, Faculty of Science, University of Novi Sad, Trg Dositeja Obradovića \\ 3, 21000 Novi Sad (e-mail: vule@ih.ns.ac.yu) and ${ }^{2}$ Vinča Institute of Nuclear Sciences, \\ Laboratory of Theoretical Physics and Condensed Matter Physics, P. O. Box 522, \\ 11001 Belgrade, Serbia and Montenegro \\ (Received 23 December 2004)
}

\begin{abstract}
The most important results of extensive studies (syntheses, spectral, magnetic, voltammetric and structural characteristics and biological activity) of metal complexes with pyridoxal semi-, thiosemi- and isothiosemicarbazones are reviewed.
\end{abstract}

Keywords: metal complexes, pyridoxal, semicarbazide-based derivatives, syntheses, structure, physico-chemical characteristics, biological activity.

\section{CONTENTS}

1. Introduction

2. Syntheses and general physical characteristics of the ligands

3. Coordination mode

4. Complexes: syntheses, physico-chemical charcteristics and geometric configuration

5. Structural characteristics

6. Spectral characteristics

7. Electrochemistry

8. Biological activity

9. Other characteristics

10. Conclusion

\section{INTRODUCTION}

Semi-, thiosemi-, and isothiosemicarbazones, (SC, TSC, ITSC, respectively) (Fig. 1), as well as their metal complexes have been the subject of great interest of many researchers for a number of years. The statement is supported by the large number of papers, among them several reviews, ${ }^{1-9}$ while isothiosemicarbazides

* Author for correspondence.

\# Serbian Chemical Society active member. 

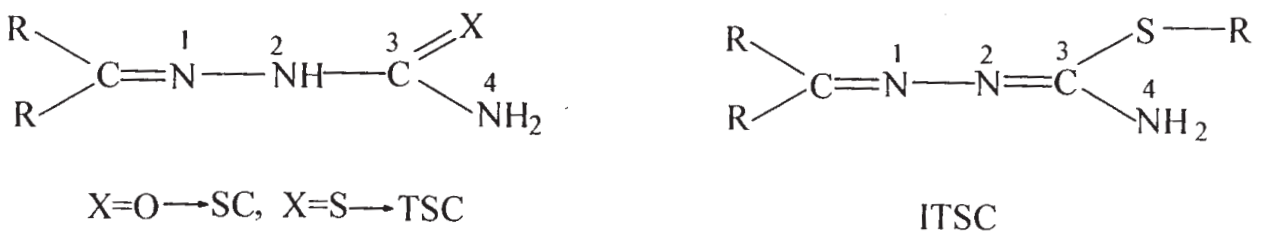

ITSC

Fig. 1. General structural formulas of semi- thiosemi- and isothiosemicarbazones.

and isothiosemicarbazones were the subject of a monograph. ${ }^{10}$ The significance of these compounds, apart from their diverse chemical and structural characteristics, stems not only from their potential but also their proved application as biologically active molecules a wide spectrum of activity. This is especially related to thiosemicarbazones and their metal complexes, for which the relationship between structure and biological activity has been covered in papers by West et al. ${ }^{3,4}$ Furthermore, bearing in mind that many semi- and thiosemicarazones form stable colored metal complexes, some of them have been proposed as analytical reagents. ${ }^{7}$ The coordination chemistry of semi-. thiosemi- and isotiosemicarbazones appeared to be very interesting from the point of view of both the number of metals forming complexes with them and the diversity of the ligand systems themselves (among them being also macrocyclic ones ${ }^{8,10-13}$ ) i.e., their denticity, set of donor atoms, stabilization of various (less common) oxidation states of metals, ${ }^{14,15}$ reactions of coordinated ligands, ${ }^{13,16,17}$ etc.

The investigation of metal complexes with Schiff bases derived from pyridoxal (PL), e.g., 3-hydroxy-5-hydroxymethyl-2-methylpyridine-4-carboxaldehyde (one of the forms of vitamin B6), and amines, and/or amino acids, have also been the subject of great interest of many researchers. ${ }^{18-21}$ The primary reason for this lies in the fact that these compounds can serve as models for studying a wide range of biological reactions which are catalyzed by enzymes, in which pyridoxal phosphate (PLP), as the physiologically active form of pyridoxal, appears as an essential component. ${ }^{18,22}$ It has been shown that in the presence of metal ions, free pyridoxal can catalyze a variety of metabolic reactions, e.g., of amino acids (transmination, decarboxylation, racemization and carbon-carbon bond cleavage), in which PLP acts as a co-enzyme. ${ }^{18,23}$ On the other hand, some recent pharmacological studies of Schiff bases of pyridoxal and aminoguanidine enabled Japanese authors ${ }^{24}$ to set up the hypothesis that this Schiff base is more effective than aminoguanidine, which is known as a good inhibitor of the formation of advanced glycation end products, and is considered to be promising for the treatmenf of diabetic complications.

In view of the fact that Schiff bases of pyridoxal are effective ligands, they are of research interest to coordination chemists. Pyridoxal semi-, thiosemi- and isothiosemicarbazones (PLSC, PLTSC and PLITSC, respectively) (Fig. 2) form a special group of these ligands. 

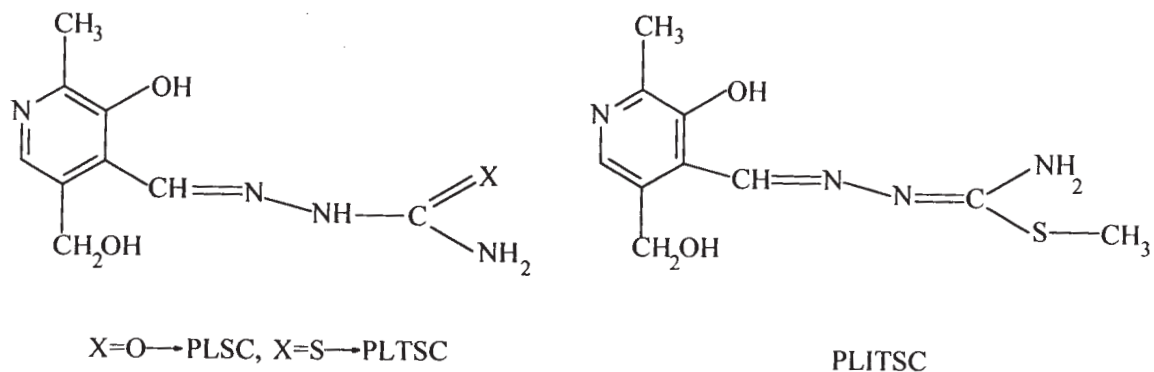

PLITSC

Fig. 2. Structural formulas of pyridoxal semi- (PLSC), thiosemi-(PLTSC) and isothiosemicarbazone (PLITSC).

This review presents the most important results which have been obtained in the studies of these ligands and their metal complexes.

\section{SYNTHESES AND GENERAL PHYSICAL CHARACTERISTICS OF THE LIGANDS}

Like the majority of similar Schiff bases, pyridoxal semi-, thiosemi- and isothiosemicarbazones are mainly obtained in good yield by the condensation reaction of aqueous or alcoholic solutions of pyridoxal and the corresponding semicarbazide derivative. ${ }^{25-27}$ Depending on the form (neutral, protonated) of the ligand precusor, i.e., of the presence of a proton acceptor $\left(\mathrm{CO}_{3}{ }^{2-}, \mathrm{OAc}^{-}\right)$, it is possible to obtain either neutral or protonated forms of the ligands ${ }^{28}$ (Scheme 1). In the case of PLTSC the preparation of its trihydrated ${ }^{25}$ and anhydrous ${ }^{29}$ forms have been reported.

All three ligands (PLSC, PLTSC, and PLITSC) are yellowish substances, sparingly soluble in water and organic solvents, whereby the protonated forms exibit somewhat higher solubility. On heating, especially in the presence of metal ions, due to complexation, their solubility shows a dramatic increase. The molar conductivity of aqueous solutions of the protonated forms of these ligands coresponds to 1:1 type of electrolytes. Both ligand forms (neutral and protonated) are characterized by enhanced thermal stability and they melt in the range from $212{ }^{\circ} \mathrm{C}$ (PLITSC $\cdot \mathrm{H}_{2} \mathrm{O}$ ) to $245^{\circ} \mathrm{C}\left(\mathrm{PLSC} \cdot \mathrm{HCl} \cdot \mathrm{H}_{2} \mathrm{O}\right) .{ }^{28}$ In addition to the mentioned unsubstituted derivatives, in the case of PLTSC, some, mainly N4-substituted (alkyl and aryl), derivatives have been prepared..$^{30}$

\section{COORDINATION MODE}

The common coordination mode of these ligands is presented in Fig. 3. As can be seen, of seven potential ligator atoms of all three ligands, three are engaged in coordination, two of them being identical for all three ligands. Namely, the identical ligators are the phenolic oxygen and hydrazine N1 nitrogen. In the case of PLSC and PLTSC, the third ligator atom is the oxygen or sulfur atom of the amide, i.e., thioamide group (Fig. 3 a,b,c). In the case of PLITSC, the third ligator atom is the N4 nitrogen of the 


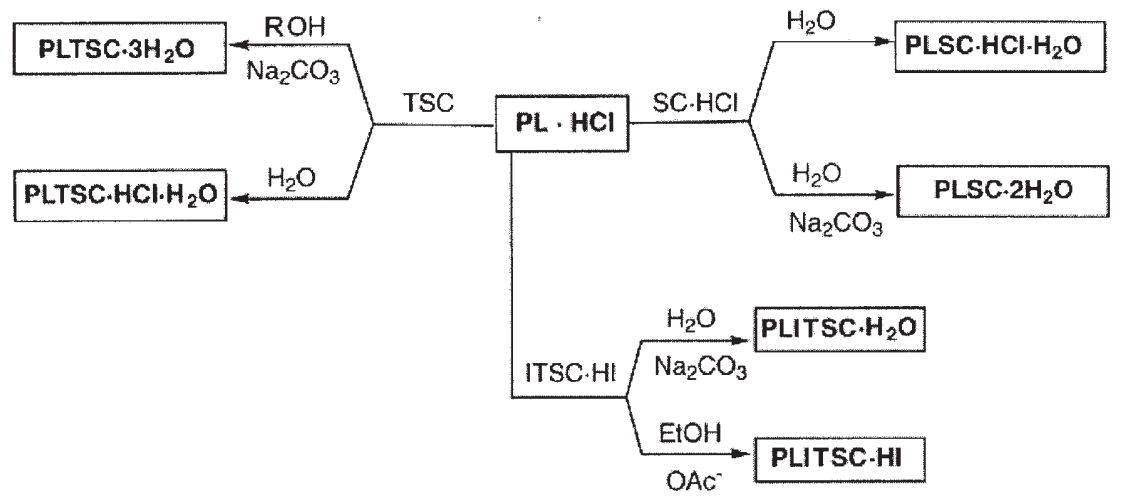

Scheme 1: Syntheses of the ligands.

isothioamide group (Fig. 3d, e, f). In all cases, two metallocycles are formed: one six-membered (pyridoxilydene) and one five-membered (semicarbazide derivative). Furthermore all three ligands can be coordinated either in neutral, monoanionic or dianionic forms. The monoanionic forms of PLSC and PLTSC are formed by deprotonation of the enol/thiol forms (Fig. 3b), and in the case of PLITSC, by deprotonation of the hydrazine nitrogen atom (Fig. 3e), i.e., of the imido form of the isothiosemicarbazide residue*. The dianionic forms of all three ligands are formed by the additional deprotonation of the pyridine nitrogen (Fig. $3 \mathrm{c}, \mathrm{f}$ ), i.e., of the zwitter ion, the existence of which is explained by the migration of the hydrogen atom from the phenolic $\mathrm{OH}$ group to the heterocyclic nitrogen atom. It should be pointed out that this proton transfer is characteristic not only of coordinated but also of non-coordinated pyridoxal derivatives, which in the case of PLTSC $3 \mathrm{H}_{2} \mathrm{O}$ was proved by solviing its molecular structure by X-ray crystallography 25 (vide infra). That is, it was found that the angle in the non-protonated pyridine nitrogen increases from $\approx 120^{\circ}$ to $\approx 124^{\circ}$, which is characteristic for the pyridine $\mathrm{C}-\mathrm{NH}-\mathrm{C}$ angle. However, in contrast to this, the $\mathrm{N}$-nonprotonated form was found in the structure of PLTSCMe ${ }_{2} \cdot \mathrm{H}_{2} \mathrm{O}\left(\mathrm{PLTSCMe}_{2}\right.$ $=$ pyridoxal N4,N4-dimethylthiosemicarbazone) ${ }^{30} \mathrm{IR}$ spectroscopic proof of the existence of the $\mathrm{NH}^{+}$group, i.e., of the dipolar nature of the PL residue, is the appearance of one or more bands at about $2850 \mathrm{~cm}^{-1}$, which, apart from the $v(\mathrm{NH})^{+}$, can also belong to the $v(\mathrm{OH})$ of hydroxymethyl groups. ${ }^{25,29}$

In view of the mentioned deprotonation sequence, the form of the coordinated ligand will depend primarily on the $\mathrm{pH}$ and then on the nature of the metal ion. Namely, the presence of proton acceptors $\left(\mathrm{NH}_{3}, \mathrm{OAc}^{-}, \mathrm{Py}\right.$, etc. $)$ will facilitate the formation of complexes with the anionic forms of the ligand. Thus, for example, with $\mathrm{Zn}\left(\mathrm{NO}_{3}\right)_{2}$ and $\mathrm{Ni}\left(\mathrm{NO}_{3}\right)_{2}$, PLTSC give $\left[\mathrm{Zn}(\mathrm{PLTSC})\left(\mathrm{NO}_{32}\right) \cdot \mathrm{H}_{2} \mathrm{O}\right.$ and $\left[\mathrm{Ni}(\mathrm{PLTSC}-\mathrm{H}) \mathrm{NO}_{3}\right] \cdot 2 \mathrm{H}_{2} \mathrm{O}$, whereas with $\mathrm{M}(\mathrm{OAc})_{2} \cdot \mathrm{H}_{2} \mathrm{O},(\mathrm{M}=\mathrm{Zn}, \mathrm{Ni})$, it forms $[\mathrm{Zn}(\mathrm{PLTSC}-\mathrm{H}) \mathrm{OAc}] \cdot \mathrm{H}_{2} \mathrm{O}$ and

\footnotetext{
* Free (non-coordinated) isothiosemicarbazones contain the isothiosemicarbazide fragment in the amido form $\left(=\mathrm{N}-\mathrm{N}=\mathrm{C}-\left(\mathrm{NH}_{2}\right)-\mathrm{SR}\right)$, and the coordinated ones in the imido form $(=\mathrm{N}-\mathrm{NH}-\mathrm{C}=(\mathrm{NH})-\mathrm{SR})$ ("prototropic tautomerism"). ${ }^{10}$
} 
<smiles></smiles>

(a)<smiles>Cc1ncc(CO)c2c1OCN1N=C(N)OC21</smiles>

(b)

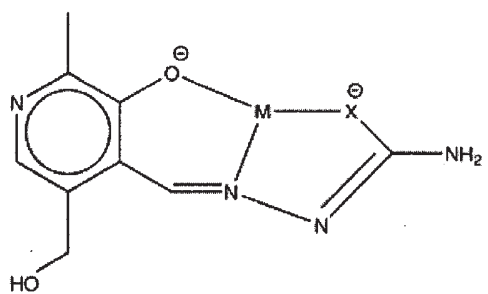

(c)<smiles></smiles>

(d)<smiles></smiles>

(e)<smiles>CSC1=NN2c3c(CO)cnc(C)c3ON2N1</smiles>

(f)

Fig. 3. Coordination modes and ligand forms of PLSC, PLTSC (a, b, c) and PLITSC (d, e, f).

$[\mathrm{Ni}(\mathrm{PLTSC}-2 \mathrm{H})] \cdot 2 \mathrm{H}_{2} \mathrm{O} .{ }^{25}$ By comparing the deprotonation of these three ligands, i.e., the deprotonation of the residue of the semicarbazide derivative, it can be concluded that thiosemicarbazide is most readily deprotonated and that deprotonation of isothiosemicarbazide is the most difficult. ${ }^{28}$

Finally, it should be noticed that in the case of PLTSC, with which, by far, the largest number of complexes have been prepared compared with the other two ligands, there are, in our opinion, two exceptions from the common tridentate ONS coordination. Thus, for examaple, in the mixed-ligand Au(III) complex of the formula $[\mathrm{Au}(\mathrm{HDAMP}) \mathrm{Cl}(\mathrm{PLTSCMe})] \mathrm{Cl}_{2},{ }^{31}$ where HDAMP $=2-(N, N$-dimethylamino-methyl)phenyl, and PLTSCMe = pyridoxal N4-methylthiosemicarbazone, the 
pyridoxal derivative is coordinated as a bidentate NIS entity, which means that the phenolic oxygen is not included in the coordination. ${ }^{31}$ The absence of coordinations of the phenolic oxygen has also been found with the similar tridentate ONS salicylaldehyde thiosemicarbazone (SALTSC), which in complexes of the type $\left[\mathrm{M}\left(\mathrm{PPh}_{3}\right)_{2}(\mathrm{SALTSC}-\mathrm{H})_{2}\right](\mathrm{M}=\mathrm{Ru}(\mathrm{II}), \mathrm{Os}(\mathrm{II})$, is also coordinated as a bidentate (NS) moiety, the TSC residue in this case is not coordinted via the N1 but via the hydrazine nitrogen, $\mathrm{N}_{2}$, thus forming a four-membered ring. ${ }^{32}$ The same coordination mode (N2S, instead of the usual N1S) of the coordinating thiosemicarbazone residue, apart from the mentioned complexes, has also been found in the case of complexes with some other thiosemicarbazones, such as Tl(III) and Ru(II) complexes with bidentale thiosemicarbazone, derivatives of benzaldehyde and acetylferrocene. ${ }^{33-35}$

Another very interesting coordination mode, characteristic not only of PLTSC but also of the other tridentate thiosemicarbazones in general, has been found in the dimeric $\mathrm{Tl}(\mathrm{III})$ complex of the formula $\left[\mathrm{TIMe}_{2}(\mathrm{PLTSC}-\mathrm{H})\left(\mathrm{H}_{2} \mathrm{O}\right)\right]_{2}$ (Fig. 4). ${ }^{36}$ It can be seen that PLTSC anion in its thiol form is bidentately coordinated via the enolyzed sulfur atom and, unexpectedly, via the oxygen atom of the undeprotonated phenolic hydroxyl, forming thus a nine-membered metallocycle. Monomeric [TIMe 2 (PLTSC-H $)\left(\mathrm{H}_{2} \mathrm{O}\right)$ units are more weakly bound in the dimer via the sulfur atom. Thus, the coordination behavior of this ligand is interesting also because the PL fragment appears in the form of a zwitter ion and neither of the hydrazine nitrogen atoms participates in the coordination. The absence of hydrazine nitrogen atoms from the coordination (i.e., the occurrence of the monodentate S-coordination only) has also been observed in some other cases. ${ }^{1,6}$ An interesting coordination behavior of PLTSC, i.e., PLTSCEt (PLTSCEt $=$ pyridoxal N4-ethylthiosemicarbazone), has been observed in the dimeric square-pyramidal complex $\left[\mathrm{Cu}\right.$ (PLTSCEt) $\mathrm{Cl}_{2} \mathrm{Cl}_{2}$, in which this ligand, apart from the usual ONS set of donor atoms, is also coordinated via the alcohol oxygen atom as a bridge. ${ }^{37}$ Furthermore, in the coordination chemistry of thiosemicarbazones in general, there are also some other exceptions to the common coordination mode, one of them being the absence of the sulfur atom from coordination. 1,13,38-40 Similar exceptions, i.e., the absence from coordination of the oxygen atom of the amide group and of the N4 nitrogen of the isothioamide group, have also been found in the structures of complexes with semi- and isothiosemicarbazones, respectively. $10,41-43$

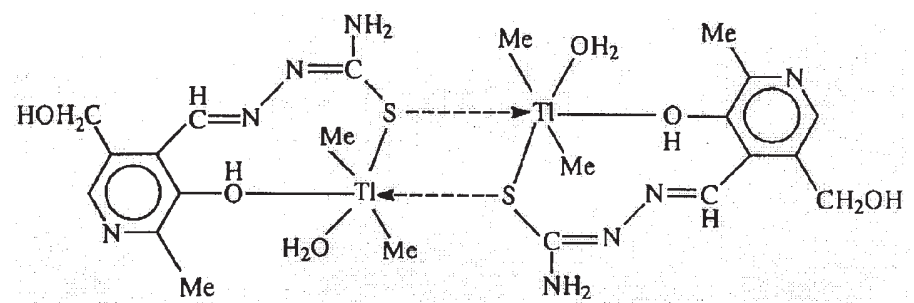

Fig. 4. Structure of $\left[\mathrm{TIMe}_{2}(\mathrm{PLTSC}-\mathrm{H})\left(\mathrm{H}_{2} \mathrm{O}\right)\right]_{2}$. 
Finally, it should be stated that, to the best of our knowledge, in the coordination chemistry of Schiff bases - pyridoxal derivatives, the subject of this review, no report has appeared of a case of the pyridine nitrogen being coordinated. However, coordination of this nitrogen atom has been postulated ${ }^{44}$ to occur in a solution of PL itself and $\mathrm{Cu}(\mathrm{II})$, and was proved in the crystal of the polymeric square-pyramidal (pyridoxylidene-DL-valinato)copper(II) complex, in which this commonly tridenate Schiff base, in addition to the oxygen atoms of the phenolic $\mathrm{OH}$ and carboxylic groups and imino nitrogen atom, is also coordinated via the pyridine nitrogen atom and the oxygen from the hydroxymethyl group of a neighboring molecule. ${ }^{45}$ Coordination of the pyridine nitrogen atom has also been found ${ }^{46}$ in the surface of the $\mathrm{Cu}(\mathrm{II})$ complex, but with pyridoxine (PN), i.e., 2-methyl-3-hydroxy-4,5-dihydroxymethylpyridine (one of the forms of vitamin $\left.\mathrm{B}_{6}\right)$ of the formula $\left[\mathrm{Cu}(\mathrm{PN})(\mathrm{PN}-\mathrm{H}] \mathrm{NO}_{3}\right.$. Namely, the neutral $\mathrm{PN}$ molecule in the form of a zwitter ion is coordinated to copper in the usual way, i.e., via two oxygen atoms (from the $\mathrm{OH}-$ and $\mathrm{CH}_{2} \mathrm{OH}-$ groups), while the deprotonated $\mathrm{PN}-\mathrm{H}$ ligand, in addition to these two atoms, is also coordinated via the pyridine nitrogen, but to the neighboring copper atom. Monodentate $N$-coordination of PN has also recently been confirmed by X-ray structural analysis of the $\mathrm{Pd}(\mathrm{II})$ complex of the formula $\left[\mathrm{Pd}(\mathrm{OX})(\mathrm{PN})_{2}\right](\mathrm{OX}=$ oxalate $) .{ }^{47}$

\section{COMPLEXES: SYNTHESES, PHYSICO-CHEMICAL CHARACTERISTICS AND GEOMETRIC CONFIGURATION}

The largest group of metal complexes with Schiff bases which have been synthesized and characterized up to now, represent complexes with PLTSC. The basic reason for this is the fact that the preparative coordination chemistry of the PLTSC ligand began the first (in 1986) with the paper of Italian authors, ${ }^{25}$ who have shown a continuous interest in this ligand and its derivatives and complexes. In contrast to this ligand, the preparative coordination chemistry of the other two ligands (PLSC, PLITSC) is of a much more recent date, and for the present it is a research subject of Leovac et al. 26,27

With respect to the applied methods and synthesis conditions of metal complexes bearing these ligands, it can be said that practically all complexes were obtained by the simple non-template method, i.e., by the reaction of ready-made ligands and metal salts, mainly in warm alcoholic (less often aqueous) solution under an air atmosphere. Some of the complexes were obtained by the template method, for example the pentacoordinated monomeric and dimeric $\mathrm{Zn}$ complexes with PLTSC of the formulas [Zn(PLTSC) $\left.\mathrm{Cl}_{2}\right] \cdot 2 \mathrm{H}_{2} \mathrm{O}$ and $\left[\left\{\mathrm{Zn}(\mathrm{PLTSC}-\mathrm{H}) \mathrm{Cl}_{2}\right] \cdot 2 \mathrm{H}_{2} \mathrm{O}\right.$ (Cl-bridge), which were prepared by the reaction of an $\mathrm{EtOH}\left(\right.$ or $\left.\mathrm{H}_{2} \mathrm{O}\right)$ solution of $\mathrm{ZnCl}_{2}, \mathrm{PL}$ and TSC (in the mole ratio $1: 1: 1$ and 2:1:1, respectively). ${ }^{48}$

From the point of view of the metals with which complexes with all three ligands have been prepared and investigated, the most numerous are, undoubtedly, copper and iron complexes. In respect of their composition, a common feature of 
all these complexes is that they belong to the type of mono(Schiff-base)-ligand complexes, the composition of which can be represented by the following general formulas: $\mathrm{Cu}(\mathrm{L}) \mathrm{X}_{2} n \mathrm{H}_{2} \mathrm{O},{ }^{26,49-52} \mathrm{Cu}$ (PLTSC- $\left.\mathrm{H}\right) \mathrm{X}_{n} \mathrm{H}_{2} \mathrm{O}^{25,53,54}$ and $\mathrm{Cu}(\mathrm{L}-2 \mathrm{H}) \mathrm{A}$ (PLSC: A $=1 \mathrm{NH}_{3}, 1 \mathrm{H}_{2} \mathrm{O}^{49}$; PLTSC: $\mathrm{A}=2 \mathrm{H}_{2} \mathrm{O}^{25}$, PLITSC: $\mathrm{A}=\mathrm{NH}_{3}, \mathrm{H}_{2} \mathrm{O}, 0.5 \mathrm{MeOH}^{53}$ ), which means that, for now, the $\mathrm{Cu}(\mathrm{II})$ complexes of PLSC and PLITSC involving the monoanionic form of the ligands have not been prepared. Complexes with the dianionic forms of PLSC and PLITSC were obtained in the presence of $\mathrm{NH}_{3}(\mathrm{aq}),{ }^{28}$ and those with PLTSC in the presence of acetate. ${ }^{25}$ With respect to their color, all complexes with PLSC and PLTSC, irrespective of the degree of deprotonation, are green, the same color being also characteristic of the complexes involving the neutral form of PLITSC, in contrast to the complex with the dianionic form of PLITSC, which is dark-brown. The effective magnetic moments of the complexes with PLSC and PLITSC ( $\mathrm{Cu}$ (II) complexes with PLTSC have not been characterized yet by the magnetochemical method, the exceptions being $\mathrm{Cu}(\mathrm{PLTSC}-\mathrm{H}) \mathrm{X} 2 \mathrm{H}_{2} \mathrm{O}(\mathrm{X}=\mathrm{Cl}$, $\mathrm{Br})^{28,54}$ and $[\mathrm{Cu}(\mathrm{PLTSCR}-\mathrm{H}) \mathrm{Cl}] \mathrm{H}_{2} \mathrm{O}$ (PLTSCR = pyridoxal N4-methyl/ethyl/phenylthiosemicarbazone), have values that are characteristic of the system $\mathrm{S}=1 / 2$ at room temperature. ${ }^{55}$ The exceptions are desolvato complexes of the type $\mathrm{Cu}(\mathrm{L}-2 \mathrm{H})$ ( $\mathrm{L}=\mathrm{PLSC}$, PLITSC) which have lower values of $\mu_{\mathrm{eff}}$ (1.57 and $1.43 \mu_{\mathrm{B}}$, respectively), which indicates the involvement of antiferromagnetic interactions of the neighboring metal centers, probably being a consequence of the dimeric structure of the molecule. ${ }^{28}$

A study of the dependence of $\mu_{\text {eff }}$ of the above [Cu(PLTSCR-H)Cl] $\mathrm{H}_{2} \mathrm{O}$ complex, which was prepared from a more acidic $(\mathrm{HCl})$ aqueous solutin, on temperaature showed the presence of very weak intramolecular antiferromagnetic interactions $\left(-2 J=c a .30 \mathrm{~cm}^{-1}\right)$ between the copper(II) centres. The EPR spectra of these complexes at $77 \mathrm{~K}$ in DMSO indicate the presence of a mixture of the monomer and dimer, consistent with the dissociation of the complexes. ${ }^{55}$

Apart from those with C.N. 4 (square-planar coordination geometry), pentacoordinated $\mathrm{Cu}$ (II) complexes having deformed square-pyramidal configuration have also been prepared. In view of the mono-tridentate type of the complex, this means that, apart from the chelate ligands, the coordination also involves acidic residues, i.e., water molecules. As examples of confirmed square-planar complexes [Cu(PLTSC-H) $\left.\mathrm{H}_{2} \mathrm{O}\right] \mathrm{X} \cdot \mathrm{H}_{2} \mathrm{O}(\mathrm{X}=\mathrm{Cl}, \mathrm{Br})^{53,54}$ and $\left[\mathrm{Cu}(\mathrm{PLITSC}-2 \mathrm{H}) \mathrm{NH}_{3}\right] \cdot \mathrm{H}_{2} \mathrm{O} \cdot 0.5 \mathrm{MeOH}$ can be mentioned. ${ }^{53} \mathrm{~A}$ deformed square-pyramidal structure have, for example, [Cu(PLSC)Br 2 ], ${ }^{52}$ $\left[\mathrm{Cu}(\mathrm{PLSC} / \mathrm{PLTSC})\left(\mathrm{H}_{2} \mathrm{O}\right)_{2}\right] \mathrm{SO}_{4} \cdot 2 \mathrm{H}_{2} \mathrm{O},{ }^{28,51}\left[\mathrm{Cu}(\mathrm{PLTSC})\left(\mathrm{H}_{2} \mathrm{O}\right) \mathrm{Cl}\right] \mathrm{Cl},{ }^{50}$ and $[\mathrm{Cu}(\mathrm{PLITSC})$ $\left.\left(\mathrm{H}_{2} \mathrm{O}\right) \mathrm{NO}_{3}\right] \mathrm{NO}_{3}{ }^{26}$ complexes. To the best of our knowledge, there are no $\mathrm{Cu}$ (II) hexacoordinated complexes the structure of which has been proved by X-ray structural analysis. (Concerning the structural aspects of these and other complexes, vide infra.).

Apart from those of copper, mono(ligand) complexes of $\mathrm{Zn}, \mathrm{Mn}, \mathrm{Ni}, \mathrm{Mo}, \mathrm{Au}$, $\mathrm{Pt}, \mathrm{Tc}, \mathrm{Tl}$ and $\mathrm{Sn}$ of the formulas [Zn(PLTSC) $\left.\left(\mathrm{NO}_{3}\right)_{2}\right],{ }^{25}[\mathrm{Zn}(\mathrm{PLTSC}-\mathrm{H}) \mathrm{X}] \cdot n \mathrm{H}_{2} \mathrm{O}$ $\left(\mathrm{X}=\mathrm{Cl}, \mathrm{CH}_{3} \mathrm{COO}\right),{ }^{25,48}\left[\mathrm{Mn}(\mathrm{PLTSC})\left(\mathrm{H}_{2} \mathrm{O}\right) \mathrm{Cl}\right] \mathrm{Cl},{ }^{54}\left[\mathrm{Ni}(\mathrm{PLTSC}-\mathrm{H})\left(\mathrm{NO}_{3}\right)\right] \cdot 2 \mathrm{H}_{2} \mathrm{O}$, 
$\left[\mathrm{Ni}(\mathrm{PLTSC}-2 \mathrm{H}) \cdot 2 \mathrm{H}_{2} \mathrm{O},{ }^{25}[\mathrm{Ni}(\mathrm{PLTSC}-\mathrm{H}) \mathrm{Py}] \mathrm{NO}_{3},\left[\mathrm{Ni}(\mathrm{PLSC})\left(\mathrm{H}_{2} \mathrm{O}\right)_{3}\right]\left(\mathrm{NO}_{3}\right)_{2},{ }^{56}\right.$ $\left[\mathrm{MoO}_{2}(\mathrm{PLTSC}-2 \mathrm{H}) \mathrm{MeOH}\right],{ }^{57}$ [Au(HDAMP)Cl(PLTSCMe) $] \mathrm{Cl}_{2},{ }^{31}\left[\mathrm{Pt}(\mathrm{PLSC}-\mathrm{H}) \mathrm{Cl}_{3}\right],{ }^{27}$ $\left[\mathrm{TIMe}_{2}(\mathrm{PLTSC}-\mathrm{H})\left(\mathrm{H}_{2} \mathrm{O}\right)\right],{ }^{36}\left[\mathrm{SnR}_{2}(\mathrm{PLTSC}-2 \mathrm{H})\right]\left(\mathrm{R}=\right.$ alkyl ${ }^{58}$ have also been obtained.

Complexes of $\mathrm{Tl}$, i.e., $\mathrm{Sn}$, have been prepared by prolonged refluxing of ethanolic solutions of PLTSC with $\mathrm{TlMe}_{2} \mathrm{OH}$, i.e., diorganotin(IV)oxide and PLTSC in benzene. On the basis of the given coordination formulas and usual mode of ligand coordination (the exceptions being $\mathrm{Tl}$ and Au complexes, $\mathrm{SN}$-coordination), it can be concluded that among the isolated compounds there are not only tetra- and penta-, but also hexacoordinated complexes, i.e., those having an octahedral structure (Mo and Pt complexes). In the case of $\left[\mathrm{Ni}(\mathrm{PLSC})\left(\mathrm{H}_{2} \mathrm{O}\right)_{3}\right]$ $\left(\mathrm{NO}_{3}\right)_{2}$, the structure was confirmed by X-ray structural analysis. ${ }^{56}$ There is a report ${ }^{59}$ describing the reaction of $\mathrm{TeO}_{4}{ }^{-}$and PLTSC, but it is not possible to unambigously establish from it the composition of the obtained complex.

Several cobalt complexes with PLTSC and one with PLITSC have been isolated. In these complexes, depending on the reaction conditions, this metal can be stabilized either in its lower $(+2)$ or higher $(+3)$ oxidation state. Thus, the reaction of an EtOH solution of $\mathrm{CoX}_{2} \cdot n \mathrm{H}_{2} \mathrm{O}\left(\mathrm{X}=\mathrm{NO}_{3}, \mathrm{OAc}\right)$ and PLTSC (1:1 mole ratio) yields brown $\mathrm{Co}$ (II) complexes of the general formula $\mathrm{Co}(\mathrm{PLTSC}-\mathrm{H}) \mathrm{X} \cdot n \mathrm{H}_{2} \mathrm{O} \cdot{ }^{25} \mathrm{It}$ is interesting to note that the reaction not only with $\mathrm{Co}(\mathrm{OAc})_{2}$, but also with $\mathrm{Co}\left(\mathrm{NO}_{3}\right)_{2}$, results in a complex with the monoanionic form of the ligand. However, if this reaction is performed in an aqueous solution, the result is an octahedral bis(ligand) cobalt(III) neutral complex, of the formula [Co(PLTSC-H) (PLTSC-2H)] $4.5 \mathrm{H}_{2} \mathrm{O}$, with non-equivalent PLTSC molecules: one molecule being singularly and the other doubly deprotonated. ${ }^{60}$ The same (neutral) type of Co(III) complex, but with the composition [Co(PLTSC $\left.-1.5 \mathrm{H})_{2}\right] \cdot 3.5 \mathrm{H}_{2} \mathrm{O}$, was obtained by recrystallization of the viscous product from a $\mathrm{CHCl}_{3}-\mathrm{MeOH}$ mixture, formed in a boiling $\mathrm{CHCl}_{3}-\mathrm{MeOH}$ ligand solution and a methanolic solution of $\mathrm{Co}(\mathrm{OAc})_{2} \cdot{ }^{60}$ In contrast to the previous complex, this complex contains equivalent PLTSC molecules. Namely, the pyridine nitrogen atoms in both ligand molecules are "semiprotonated", the conclusion being supported by the existence of a strong symmetric. $\mathrm{N} \cdots \cdot \mathrm{H} \cdots \mathrm{N}$ hydrogen bond $(2.685 \AA)$ between the pyridine nitrogens of neighboring molecules. Due to the ligand planarity, both complexes have a mer-octahedral configuration. Another bis(ligand) octahedral complex of PLTSC and $\mathrm{Co}(\mathrm{III})$ has been described, but a monocationic one, $\left[\mathrm{Co}(\mathrm{PLTSC}-\mathrm{H})_{2}\right] \mathrm{Cl} \cdot \mathrm{EtOH}$, which was obtained in the reaction of $\mathrm{CoCl}_{2}$ and PLTSC (mole ratio 1:1) in EtOH. On the basis of the analysis of $\mathrm{CD}$ spectra, it was concluded that spontaneous resolution takes place in solution, yielding a complex of the absolute configuration $\Lambda .{ }^{61}$ Recently, an octahedral bis(ligand) neutral complex of $\mathrm{Co}(\mathrm{III})$ and PLITSC, viz. [Co(PLITSC-H) (PLITSC-2H)] $\cdot \mathrm{MeOH}$, has been prepared. ${ }^{56}$ 
Apart from copper, iron is the other element whose complexes with all three ligands (L) have been prepared. These are: monocationic mono- and bis(ligand) $\mathrm{Fe}(\mathrm{III}) \mathrm{com}-$ plexes $\left[\mathrm{Fe}(\mathrm{L}) \mathrm{Cl}_{2}\left(\mathrm{H}_{2} \mathrm{O}\right)\right] \mathrm{Cl},\left[\mathrm{Fe}(\mathrm{L}-\mathrm{H})_{2}\right] \mathrm{X} \cdot n \mathrm{H}_{2} \mathrm{O}$, and in the case of PLITSC, the dicationic bis(PLITSC) complex [Fe(PLITSC)(PLITSC-H)] $\left(\mathrm{NO}_{3}\right)_{2} \cdot \mathrm{H}_{2} \mathrm{O}$, also. ${ }^{29,62,63}$ The complexes were obtained in reactions of warm EtOH solutions of $\mathrm{Fe}(\mathrm{III})$ and ligand in the appropriate mole ratio. Furthermore, with PLSC and PLTSC, a neutral bis(ligand) $\mathrm{Fe}(\mathrm{III})$ complex $[\mathrm{Fe}(\mathrm{L}-\mathrm{H})(\mathrm{L}-2 \mathrm{H})] \cdot 4 \mathrm{H}_{2} \mathrm{O}$ was obtained, ${ }^{63}$ which is analogous to the $\mathrm{Co}$ (III) complexes discussed above. This type of $\mathrm{Fe}$ (III) complex was obtained by the reaction of a $\mathrm{MeOH}$ solution of $\left[\mathrm{Fe}\left(\mathrm{L}-\mathrm{H}_{2}\right] \mathrm{Cl} \cdot n \mathrm{H}_{2} \mathrm{O}\right.$ with $\mathrm{NH}_{3}$ (aq). In addition to those with PLTSC and PLSC, the complex [Fe(PLTSC-H)Cl ${ }_{2}$ )] was prepared by the reaction of an EtOH solution of $\mathrm{FeCl}_{2}$ and PLTSC (whereby $\mathrm{Fe}(\mathrm{II})$ was oxidized to $\mathrm{Fe}(\mathrm{III})^{64}$ ) and [ $\left.\mathrm{Fe}(\mathrm{PLSC})\left(\mathrm{SO}_{4}\right)\left(\mathrm{H}_{2} \mathrm{O}\right)_{2}\right]$ (reaction of $\mathrm{H}_{2} \mathrm{O}$ solution of $\mathrm{FeSO}_{4}$ with the ligand). ${ }^{65}$ The last complex is, at present, the only $\mathrm{Fe}(\mathrm{II})$ complex with this class of ligands. The dicationic bis(PLITSC) complex, which contains one neutral and one singley-deprotonated ligand, represents a very rare example of such a combination of ligands in bis(tridentate) complexes. With the exception of $\left[\mathrm{Fe}(\mathrm{PLTSC}-\mathrm{H}) \mathrm{Cl}_{2}\right]$, which has a square-pyramidal configuration, all the other complexes have octahederal configuration. In the case of $\left[\mathrm{Fe}(\mathrm{PLSC})\left(\mathrm{SO}_{4}\right)\left(\mathrm{H}_{2} \mathrm{O}\right)_{2}\right]$, the trans $\left(\mathrm{H}_{2} \mathrm{O}\right)$ isomer was isolated, ${ }^{65}$ and in the case of $\left[\mathrm{Fe}(\mathrm{L}) \mathrm{Cl}_{2}\left(\mathrm{H}_{2} \mathrm{O}\right)\right] \mathrm{Cl}(\mathrm{L}=$ PLSC, PLTSC), the $c i s(\mathrm{Cl})$ isomer. ${ }^{66,67}$

The complexes are well soluble in DMF, less soluble in $\mathrm{MeOH}$, EtOH and $\mathrm{H}_{2} \mathrm{O}$, those of the type $\left[\mathrm{Fe}(\mathrm{L}) \mathrm{Cl}_{2}\left(\mathrm{H}_{2} \mathrm{O}\right)\right] \mathrm{Cl}$ being, generally, the most soluble. Values of $\lambda_{\mathrm{M}}$ of this type of complex in $\mathrm{H}_{2} \mathrm{O}$ solution correspond to 1:3 type of electrolytes, which is explained in terms of the total replacement of coordinated $\mathrm{Cl}$ ions with $\mathrm{H}_{2} \mathrm{O}$ molecules. ${ }^{62}$ Moreover, the $\lambda_{\mathrm{M}}$ value of the PLTSC complexes corresponds to 1:4 type of electrolytes, which is, apparently, a consequence of the deprotonation of the TSC fragment and the formation of the mobile $\mathrm{H}_{3} \mathrm{O}^{+}$ion.

With the exception of $\left[\mathrm{Fe}(\mathrm{PLTSC}-\mathrm{H})_{2}\right] \mathrm{Cl}$ and $\left[\mathrm{Fe}(\mathrm{PLITSC}) \mathrm{Cl}_{2}\left(\mathrm{H}_{2} \mathrm{O}\right)\right] \mathrm{Cl}$, which are spin-only, that is [ $\left.\mathrm{Fe}(\mathrm{PLTSC}-\mathrm{H})_{2} \mathrm{Cl}\right] \cdot 2 \mathrm{H}_{2} \mathrm{O}$ and [ $\left.\mathrm{Fe}(\mathrm{PLTSC}-\mathrm{H})(\mathrm{PLTSC}-2 \mathrm{H})\right] \cdot 4 \mathrm{H}_{2} \mathrm{O}$, which are low-spin, all the other complexes have somewhat lowered $\mu_{\text {eff }}$ values compared with purely high-spin Fe(III) complexes. ${ }^{29,62,63}$ This can be explained by the existence of "admixtures" of the low-spin Fe(III). It is interesting to notice that the PLTSC complexes belong to groups differing in respect of their spin, which is in agreement with the literature data that the spin state of bis(tridentate) TSCs complexes of $\mathrm{Fe}(\mathrm{III})$ can depend on both the nature of the outer-sphere ion and the crystallohydrate composition of the complex. ${ }^{68}$ Measurements of the temperature dependence of $\mu_{\text {eff }}$ values for [Fe(PLTSC-H) $\left.)_{2}\right] \mathrm{Cl}$ showed that this complex is high-spin $\left(\mu_{\text {eff }}=5.75 \mu_{\mathrm{B}}\right.$ at $299 \mathrm{~K}$, and that $\mu_{\text {eff }}$ decreases with decreasing temperature $\left(\mu_{\mathrm{eff}}=4.00(245 \mathrm{~K}), 2.26(345 \mathrm{~K})\right.$, and $\left.2.01 \mu_{\mathrm{B}}(78 \mathrm{~K})\right) .{ }^{29}$ On the basis of the magnetism, the transition temperature of this spin-crossover complex, asso- 
ciated with the ${ }^{6} \mathrm{~A}_{1}$ (high-spin) $\leftrightarrow{ }^{2} T_{2}$ (low-spin) transition, is well defined as $T_{\mathrm{c}}$ $(\downarrow)=245 \mathrm{~K}$. For the reverse transition occurring upon sample heating, $T_{\mathrm{c}}(\uparrow)=256$ $\mathrm{K}$ (the thermal histeresis being $11 \mathrm{~K}$ ). Variable temperature ${ }^{57} \mathrm{Fe}$ Mössbauer data also provide evidence for the presence of a spin transition in this complex. An analogous phenomenon, but appearing as a consequence of the nature of the substituted bonded to the N4 atom, was also found for $\left[\mathrm{Fe}(\mathrm{PLTSCPh}-\mathrm{H})_{2}\right] \mathrm{Cl}(\mathrm{PLTSCPh}=$ pyridoxal N4-phenylthiosemicarbazone) $\left(\mu_{\text {eff }}=5.90,(320 \mathrm{~K}), 2.14(78 \mathrm{~K})\right.$ in contrast to the same type of Fe(III) complex with N4-methyl/ethyl derivatives, which are low-spin $\left(\mu_{\text {eff }} c a .2 .12 \mu_{\mathrm{B}}\right),{ }^{69}$ in the same temperature interval.

\section{STRUCTURAL CHARACTERISTICS}

A survey of selected geometric and conformational parameters of all the ligands and their complexes which have been characterized by X-ray structural analysis are given in Tables I and II. The atom designations used in the text and Tables are given in Fig. 5.

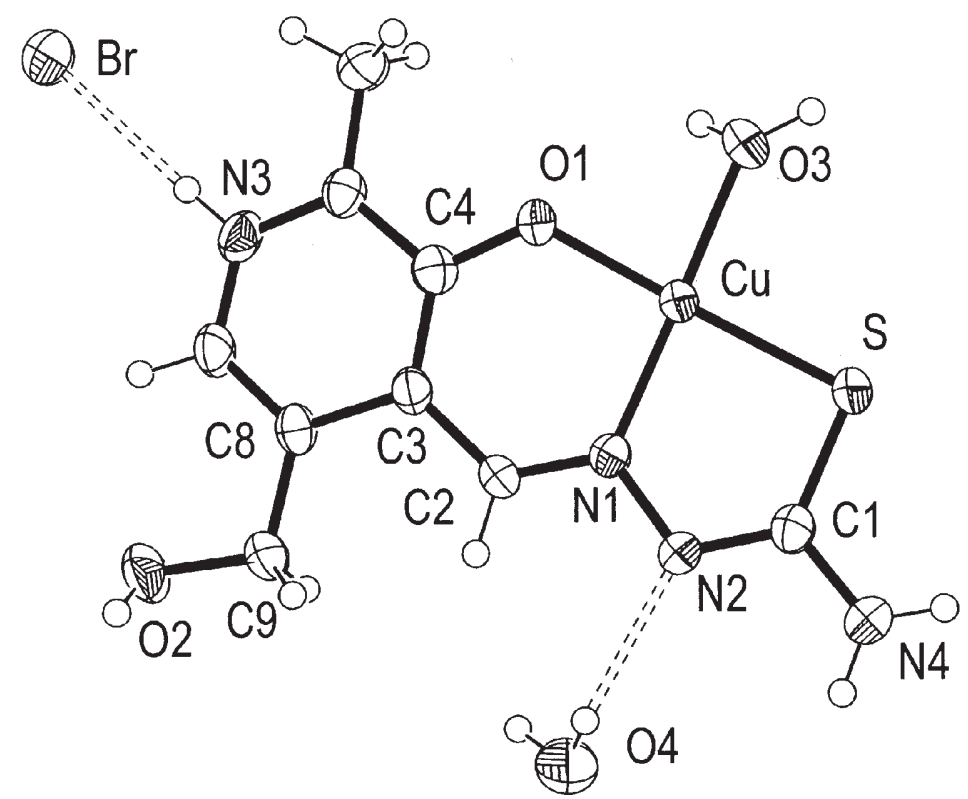

Fig. 5. ORTER drawing of complex $\mathbf{1 6}$ as an example for the usual coordination mode of PLTSC as well as an example of the atom numbering scheme used in Table I and in the discussion. The thermal ellipsoids correspond to $50 \%$ probability.

In the Tables, the crystal structures are divided into four groups. The first group contains the structures of the non-coordinated ligands ( 5 structures), the second consists of metal complexes of PLTSC (18 structures), while the third and fourth groups comprise metal complexes with PLITSC and PLSC as ligands (4 structures of each), which altogether makes 31 crystal structures. Since some of the 
structures from Table I contain two molecules of the PL ligand derivative (bis(ligand) complexes 10, 11, 12, 22, 23, 26 and 27), and since the structue 25 includes two asymmetric molecules in one asymmetric unit, the number of PL derivatives for which unique X-ray experimiental data exist increases to 39. The TSC fragment in the PLTSC ligand and its substituted derivatives is coordinated in the usual way, i.e., via the $\mathrm{N} 1$ and $\mathrm{S}$ atoms, while the PL moiety is coordinated via the oxygen atom $\mathrm{O} 1$ of the deprotonated phenolic $\mathrm{OH}$ group (Fig. 5). The exceptions are $\mathrm{Au}$ and T1 complexes ( $\mathbf{8}$ and $\mathbf{9})$, whereby $\mathbf{8}$ involves coordination of $\mathrm{N} 1$ and $\mathrm{S}$ atoms (O1 is protonated and uncoordinated), while the coordination around T1 in $\mathbf{9}$, apart from the $\mathrm{O} 1$ atom of the non-ionized phenolic group, is made of two $\mathrm{S}$ atoms from two different ligands. Namely, in 9 the $\mathrm{S}$ atom plays the role of a bridge between two adjacent T1 atoms, with T1-S distances of 2.83 and $3.19 \AA$ (Fig. 4). In the solved structures of the complexes with PLITSC and PLSC, both ligands are always coordinated in the usual way, i.e., via O1, N1, N4 (PLITSC) (Fig. 6), and O1, N1, O3 (PLSC) (Fig. 7) set of donor atoms.

TABLE I. Selected bond distances $(\AA)$ for all crystal structures of the PLTSC, PLITSC and PLSC compounds

\begin{tabular}{|c|c|c|c|c|c|c|c|c|c|}
\hline Compound* & $\begin{array}{c}\mathrm{O} 1- \\
\mathrm{C}\end{array}$ & $\begin{array}{l}\text { N1- } \\
\text { N2 }\end{array}$ & $\begin{array}{l}\mathrm{N} 2- \\
\mathrm{C} 1\end{array}$ & $\begin{array}{l}\mathrm{C} 1- \\
\mathrm{N} 4\end{array}$ & $\begin{array}{c}\mathrm{C} 1- \\
\mathrm{X}\end{array}$ & $\begin{array}{l}\mathrm{M}- \\
\mathrm{O} 1\end{array}$ & $\begin{array}{l}\text { M- } \\
\text { N1 }\end{array}$ & $\begin{array}{c}\text { M- } \\
\text { X }\end{array}$ & Ref. \\
\hline $\mathrm{PLTSC} \cdot 3 \mathrm{H}_{2} \mathrm{O}(\mathbf{1})$ & 1.29 & 1.40 & 1.35 & 1.33 & 1.70 & - & - & - & 25 \\
\hline PLTSCMe·HCl (2) & 1.34 & 1.36 & 1.38 & 1.34 & 1.67 & - & - & - & 31 \\
\hline PLTSCMeMe $\cdot \mathrm{H}_{2} \mathrm{O}(\mathbf{3})$ & 1.29 & 1.37 & 1.39 & 1.32 & 1.68 & - & - & - & 30 \\
\hline $\mathrm{PLTSCMe}_{2} \cdot \mathrm{H}_{2} \mathrm{O}(4)$ & 1.35 & 1.36 & 1.37 & 1.33 & 1.69 & - & - & - & 30 \\
\hline PLSC.HCl· $\mathrm{H}_{2} \mathrm{O}(\mathbf{5})$ & 1.34 & 1.36 & 1.38 & 1.32 & 1.23 & - & - & - & 28 \\
\hline$\left[\mathrm{Mn}(\mathrm{PLTSC})\left(\mathrm{H}_{2} \mathrm{O}\right) \mathrm{Cl}\right] \mathrm{Cl}(\mathbf{6})$ & 1.27 & 1.36 & 1.33 & 1.30 & 1.71 & 2.00 & 2.27 & 2.48 & 54 \\
\hline$\left[\mathrm{Zn}(\mathrm{PLTSC}-\mathrm{H}) \mathrm{Cl}_{2}\right]_{2} \cdot 2 \mathrm{H}_{2} \mathrm{O}(7)$ & 1.32 & 1.36 & 1.34 & 1.33 & 1.75 & 1.96 & 2.11 & 2.29 & 48 \\
\hline$[\mathrm{Au}(\mathrm{HDAMP}) \mathrm{Cl}(\mathrm{PLTSCMe})] \mathrm{Cl}_{2}(\mathbf{8})$ & 1.33 & 1.37 & 1.33 & 1.34 & 1.76 & - & 2.13 & 2.26 & 31 \\
\hline$\left[\mathrm{TIMe}_{2}(\mathrm{PLTSC}-\mathrm{H})\left(\mathrm{H}_{2} \mathrm{O}\right)\right]_{2}(\mathbf{9})$ & 1.35 & 1.34 & 1.34 & 1.33 & 1.74 & 3.12 & - & 2.83 & 36 \\
\hline$[\mathrm{Co}(\mathrm{PLTSC}-\mathrm{H})$ & 1.31 & 1.37 & 1.33 & 1.34 & 1.72 & 1.95 & 1.89 & 2.21 & 60 \\
\hline$(\mathrm{PLTSC}-2 \mathrm{H}) \cdot 4.5 \mathrm{H}_{2} \mathrm{O}(\mathbf{1 0})$ & 1.29 & 1.40 & 1.30 & 1.37 & 1.74 & 1.96 & 1.89 & 2.23 & \\
\hline \multirow[t]{2}{*}[\mathrm{Co}(\mathrm{PLTSC}-1.5\mathrm{H})_{2}]{$\cdot 3.5 \mathrm{H}_{2} \mathrm{O}(\mathbf{1 1})$} & 1.30 & 1.38 & 1.32 & 1.35 & 1.71 & 1.96 & 1.90 & 2.21 & 60 \\
\hline & 1.31 & 1.39 & 1.30 & 1.38 & 1.74 & 1.95 & 1.90 & 2.20 & \\
\hline \multirow[t]{2}{*}[\mathrm{Co}(\mathrm{PLTSC}-\mathrm{H})_{2}]{$\mathrm{Cl} \cdot \mathrm{EtOH}(\mathbf{1 2})$} & 1.26 & 1.40 & 1.33 & 1.38 & 1.69 & 1.94 & 1.88 & 2.20 & 61 \\
\hline & 1.27 & 1.41 & 1.34 & 1.39 & 1.69 & 1.93 & 1.89 & 2.21 & \\
\hline$\left[\mathrm{Cu}(\mathrm{PLTSC})\left(\mathrm{H}_{2} \mathrm{O}\right)_{2}\right] \mathrm{SO}_{4} \cdot \mathrm{H}_{2} \mathrm{O}(\mathbf{1 3})$ & 1.29 & 1.38 & 1.36 & 1.31 & 1.70 & 1.89 & 1.98 & 2.25 & 51 \\
\hline$\left[\mathrm{Cu}(\mathrm{PLTSC}) \mathrm{Cl}\left(\mathrm{H}_{2} \mathrm{O}\right)\right] \mathrm{Cl}(\mathbf{1 4})$ & 1.29 & 1.38 & 1.34 & 1.31 & 1.71 & 1.91 & 1.97 & 2.29 & 50 \\
\hline
\end{tabular}


TABLE I. Continued

\begin{tabular}{|c|c|c|c|c|c|c|c|c|c|}
\hline Compound* & $\begin{array}{c}\mathrm{O} 1- \\
\mathrm{C}\end{array}$ & $\begin{array}{l}\mathrm{N} 1- \\
\mathrm{N} 2\end{array}$ & $\begin{array}{l}\mathrm{N} 2- \\
\mathrm{C} 1\end{array}$ & $\begin{array}{l}\mathrm{C} 1- \\
\mathrm{N} 4\end{array}$ & $\begin{array}{c}\mathrm{C} 1- \\
\mathrm{X}\end{array}$ & $\begin{array}{l}\mathrm{M}- \\
\mathrm{O} 1\end{array}$ & $\begin{array}{l}\text { M- } \\
\text { N1 }\end{array}$ & $\begin{array}{c}\text { M- } \\
X\end{array}$ & Ref. \\
\hline$\left[\mathrm{Cu}(\mathrm{PLTSC}-\mathrm{H})\left(\mathrm{H}_{2} \mathrm{O}\right)\right]_{2} \mathrm{Cl}_{2} \cdot 2 \mathrm{H}_{2} \mathrm{O}(\mathbf{1 5})$ & 1.30 & 1.37 & 1.32 & 1.33 & 1.72 & 1.88 & 1.94 & 2.23 & 54 \\
\hline$\left[\mathrm{Cu}(\mathrm{PLTSC}-\mathrm{H})\left(\mathrm{H}_{2} \mathrm{O}\right)\right]_{2} \mathrm{Br}_{2} \cdot 2 \mathrm{H}_{2} \mathrm{O}$ (16) & 1.31 & 1.37 & 1.32 & 1.34 & 1.73 & 1.94 & 1.87 & 2.24 & 53 \\
\hline$\left[\mathrm{Cu}\left(\mathrm{PLTSCMe}_{2}-\mathrm{H}\right) \mathrm{Cl}\right]_{2} \cdot 6 \mathrm{H}_{2} \mathrm{O}(\mathbf{1 7})$ & 1.29 & 1.38 & 1.34 & 1.35 & 1.72 & 1.91 & 1.97 & 2.22 & 37 \\
\hline$[\mathrm{Cu}(\mathrm{PLTSCMeMe}) \mathrm{Cl}]_{2} \mathrm{Cl}_{2} \cdot 4 \mathrm{H}_{2} \mathrm{O}(\mathbf{1 8})$ & 1.29 & 1.38 & 1.36 & 1.31 & 1.70 & 1.90 & 1.99 & 2.22 & 37 \\
\hline$[\mathrm{Cu}(\mathrm{PLTSCEt}) \mathrm{Cl}]_{2} \mathrm{Cl}_{2} \cdot 2 \mathrm{H}_{2} \mathrm{O}(\mathbf{1 9})$ & 1.30 & 1.39 & 1.34 & 1.33 & 1.70 & 1.90 & 1.99 & 2.25 & 37 \\
\hline$\left[\mathrm{Fe}(\mathrm{PLTSC}-\mathrm{H}) \mathrm{Cl}_{2}\right]$ (20) & 1.32 & 1.38 & 1.33 & 1.34 & 1.73 & 1.89 & 2.20 & 2.34 & 48 \\
\hline$\left[\mathrm{Fe}(\mathrm{PLTSC})\left(\mathrm{H}_{2} \mathrm{O}\right) \mathrm{Cl}_{2}\right] \mathrm{Cl}(\mathbf{2 1})$ & 1.30 & 1.37 & 1.34 & 1.31 & 1.70 & 1.92 & 2.22 & 2.43 & 67 \\
\hline$[\mathrm{Fe}(\mathrm{PLTSC}-\mathrm{H})$ & 1.30 & 1.39 & 1.32 & 1.34 & 1.72 & 1.94 & 1.92 & 2.25 & 28 \\
\hline$(\mathrm{PLTSC}-2 \mathrm{H})] \cdot 4 \mathrm{H}_{2} \mathrm{O}(\mathbf{2 2})$ & 1.32 & 1.41 & 1.31 & 1.36 & 1.74 & 1.93 & 1.91 & 2.27 & 70 \\
\hline \multirow[t]{2}{*}[\mathrm{Fe}(\mathrm{PLTSC}-\mathrm{H})_{2}]{$\cdot 0.5 \mathrm{SO}_{4}(\mathbf{2 3})$} & 1.30 & 1.39 & 1.32 & 1.34 & 1.75 & 1.91 & 1.92 & 2.23 & 28 \\
\hline & 1.30 & 1.41 & 1.35 & 1.32 & 1.73 & 1.96 & 1.92 & 2.20 & \\
\hline$\left[\mathrm{Cu}(\mathrm{PLITSCH})\left(\mathrm{H}_{2} \mathrm{O}\right) \mathrm{NO}_{3}\right] \mathrm{NO}_{3}(\mathbf{2 4})$ & 1.29 & 1.37 & 1.36 & 1.28 & 1.75 & 1.88 & 1.97 & 1.93 & 26 \\
\hline$\left[\mathrm{Cu}(\mathrm{PLITSC}-2 \mathrm{H}) \mathrm{NH}_{3}\right]$ & 1.31 & 1.41 & 1.33 & 1.33 & 1.76 & 1.89 & 1.95 & 1.93 & 28 \\
\hline$\cdot \mathrm{H}_{2} \mathrm{O} \cdot 0.5 \mathrm{MeOH}(\mathbf{2 5})$ & 1.32 & 1.38 & 1.34 & 1.30 & 1.76 & 1.88 & 1.94 & 1.94 & 53 \\
\hline$[\mathrm{Co}(\mathrm{PLITSC}-\mathrm{H})(\mathrm{PLITSC}-2 \mathrm{H})]$ & 1.32 & 1.39 & 1.33 & 1.31 & 1.75 & 1.94 & 1.88 & 1.89 & 56 \\
\hline$\cdot \mathrm{MeOH}(\mathbf{2 6})$ & 1.29 & 1.38 & 1.32 & 1.32 & 1.75 & 1.91 & 1.89 & 1.89 & \\
\hline$[\mathrm{Fe}(\mathrm{PLITSC})(\mathrm{PLITSC}-\mathrm{H})]\left(\mathrm{NO}_{3}\right)_{2}(\mathbf{2 7})$ & 1.30 & 1.34 & 1.36 & 1.32 & 1.74 & 1.93 & 2.18 & 2.03 & 56 \\
\hline$\left[\mathrm{Cu}(\mathrm{PLSC}) \mathrm{Br}_{2}\right](\mathbf{2 8})$ & 1.29 & 1.37 & 1.36 & 1.32 & 1.25 & 1.90 & 1.99 & 1.98 & 52 \\
\hline$\left[\mathrm{Cu}(\mathrm{PLSC})\left(\mathrm{H}_{2} \mathrm{O}\right)\right] \mathrm{SO}_{4} \cdot 2 \mathrm{H}_{2} \mathrm{O}(\mathbf{2 9})$ & 1.29 & 1.37 & 1.36 & 1.31 & 1.27 & 1.88 & 1.95 & 1.95 & 56 \\
\hline$\left[\mathrm{Fe}(\mathrm{PLSC})\left(\mathrm{H}_{2} \mathrm{O}\right)_{2}\left(\mathrm{SO}_{4}\right)\right](\mathbf{3 0})$ & 1.30 & 1.37 & 1.37 & 1.33 & 1.24 & 2.02 & 2.12 & 2.13 & 65 \\
\hline$\left[\mathrm{Fe}(\mathrm{PLSC})\left(\mathrm{H}_{2} \mathrm{O}\right) \mathrm{Cl}_{2}\right] \mathrm{Cl}(\mathbf{3 1})$ & 1.31 & 1.36 & 1.37 & 1.33 & 1.26 & 1.92 & 2.20 & 2.06 & 66 \\
\hline
\end{tabular}

${ }^{*}$ PLTSCMe $=$ PL N4-methylTSC, PLTSCMeMe $=$ PL N2,N3-dimethylTSC, PLTSCMe $_{2}=$ PL N4,N4-dimethylTSC, PLTSCEt $=$ PL N4-ethylTSC

As can be seen from Table $\mathrm{I}$, the $\mathrm{C}-\mathrm{O} 1$ distance in both the free and coordinated ligands is between the value of a double $(1.23 \AA)$ and single $(1.43 \AA) \mathrm{C}-\mathrm{O}$ bond, which indicates significant delocalization of the $\pi$ electrons of the pyridine ring towards the oxygen O1. It can be seen that this bond in complexes $\mathbf{8}$ and $\mathbf{9}$ is somewhat longer (1.33 and $1.35 \AA$, respectively) than in the other complexes $\left(\mathrm{C}-\mathrm{O} 1_{\text {(average) }}=1.30 \AA\right.$ ). The reason for this lies in the fact that, in contrast to the other complexes in which the ligands are coordinted via the deprotonated phenolic $\mathrm{OH}$ group, the ligand in $\mathbf{8}$ is coordinated without participation of the oxygen of the non-ionized O1H group, and in 9 the oxygen atom of the (also non-ionized) $\mathrm{OH}$ group enters a very weak interaction with 


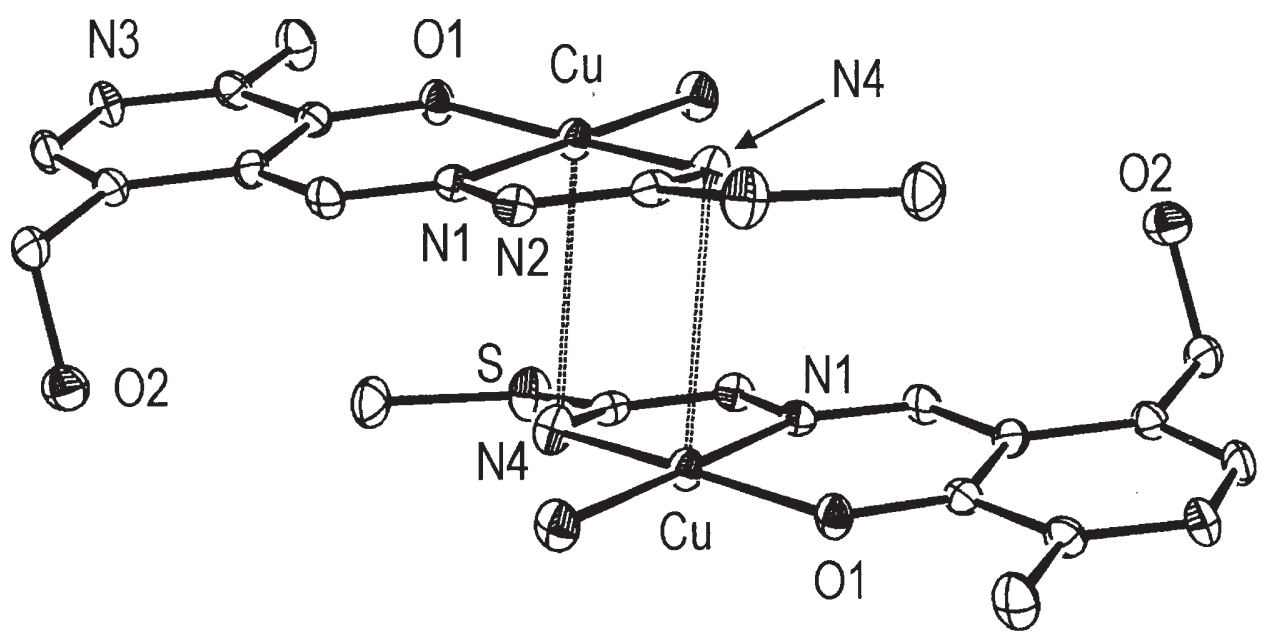

Fig. 6. View of the crystal-lattice of complex 25 illustrating by dashed lines the dimeric interactions of the $\mathrm{Cu}$ atom. Displacement ellipsoids are shown at the $20 \%$ probabilit level while the $\mathrm{H}$ atoms are omitted for clarity.

$\mathrm{T} 1(\mathrm{~T} 1-\mathrm{O}=3.12 \AA)$. Hence, it is not surprising that the $\mathrm{C}-\mathrm{O} 1$ distance in both complexes is close to the $\mathrm{C}-\mathrm{O} 1$ bond in the free ligands $\mathbf{2 , 4}$ and $\mathbf{5}$, which contain a non-ionized $\mathrm{OH}$ group. Thus, this bond in the free ligands $\mathbf{1}$ and $\mathbf{3}$ containing an ionized $\mathrm{O} 1 \mathrm{H}$ group is practically identical to the bond in the complexes in which this group is also ionized. Moreover, non-coordinated PLSC and PLTSC ligands differ also in the conformation of their semi- and thiosemicarbazide residues. While ligands $\mathbf{1 , 3}$ and 5 show an $E$ conformation around both the $\mathrm{C} 2-\mathrm{N} 1$ and $\mathrm{Cl}-\mathrm{N} 2$ bonds (the phenolic oxygen and the $\mathrm{S}$ or $\mathrm{O} 3$ atoms are trans to $\mathrm{N} 1$ ), the ligands $\mathbf{2}$ and $\mathbf{4}$ show a $Z$ conformation around the $\mathrm{Cl}-\mathrm{N} 2$ bond. It is interesting to notice that the ligands $\mathbf{1}$ and $\mathbf{5}$ have a very similar configuration, although $\mathbf{1}$ appears as a neutral entity and $\mathbf{5}$ as a hydrochloride. The differences in the conformations of the non-coordinated ligands are the consequence of the different intra- and intermolecular hydrogen bonds, crystal packing, presence/absence of $\mathrm{H}$ atom at the $\mathrm{O} 1$ and $\mathrm{N} 3$, as well as of the effect of the presence/absence of methyl groups in the TSC fragment.

By analyzing the lengths of the N1-N2, N2-Cl and Cl-N4 bonds (Table I) it can be concluded that delocalization of electronic density exists in the N1-N2-Cl-N4 fragment. It is known that in the case of the PLTSC ligand, the sulfur atom also participates in this delocalization, but to a smaller extent when the $\mathrm{S}$ atom is coordinated (Table I). Delocalization of the $\pi$ electrons in the N1-N2-Cl-N4 fragment occurs in all cases, irrespective of whether the $\mathrm{N} 2$ atom is protonated or whether the PL ligands are coordinated or not. Since the length of the $\mathrm{C} 2-\mathrm{N} 1$ bond is about $1.30 \AA$, it is quite clear that the $\mathrm{C} 2$ atom also participates in the $\pi$ delocalization from the $\mathrm{N} 1-\mathrm{N} 2-\mathrm{Cl}-\mathrm{N} 4$ fragment, making, thus, a bond between the $\pi$ system in the pyridine ring and this fragment. 

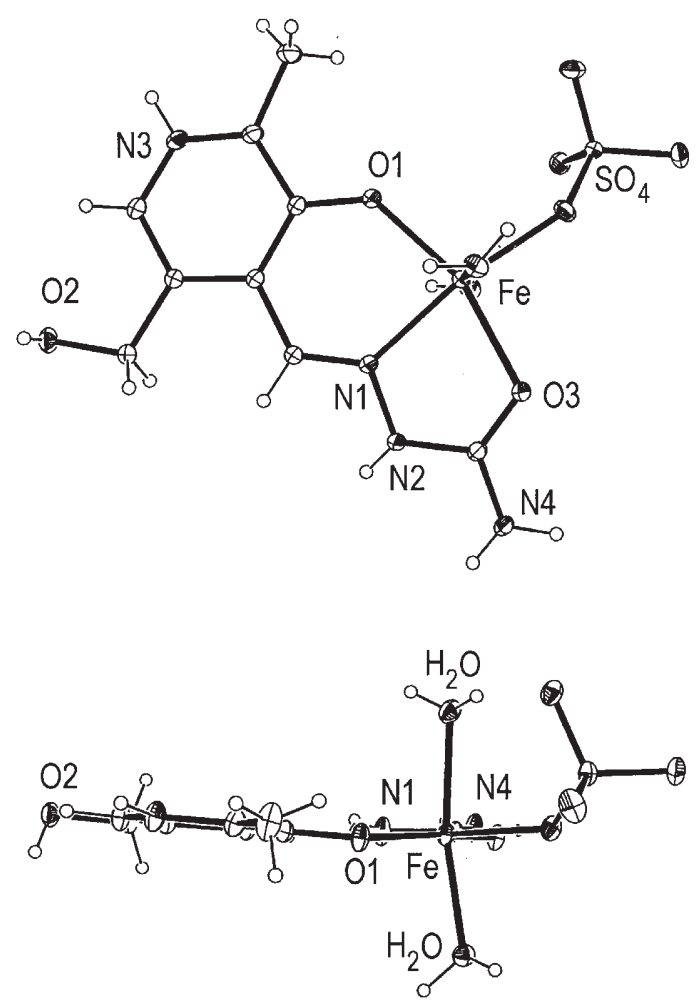

Fig. 7. Crystal structure of complex $\mathbf{3 0}$ in two orthogonal projections.

Bearing in mind the mentioned large delocalized $\pi$ system, it is not suprising that all non-hydrogen atoms in these ligands are in many cases approximately co-planar. This only does not hold for the $\mathrm{O} 2$ atom from the $-\mathrm{CH}_{2} \mathrm{OH}$ group, which can change its position by rotating around the single $\mathrm{C} 8-\mathrm{C} 9$ bond. The position of the $\mathrm{O} 2 \mathrm{H}$ hydroxyl group can be best described by the $\mathrm{O} 2-\mathrm{C} 9-\mathrm{C} 8-\mathrm{C} 3$ torsion angle (denoted as T1, Table II). The values of this torsion angle show that this group is approximately in the same plane with the pyridine ring in 10 examples. In a large number of examples (17), this torsion angle has a value in the relatively narrow interval of 60 do $70^{\circ}$ (Table II). It can be supposed that, thanks to the free rotation around the $\mathrm{C} 8-\mathrm{C} 9$ bond, the $\mathrm{O} 2 \mathrm{H}$ group assumes the position in which the most favorable hydrogen bond is realized.

On coordination, all three ligands form two fused chelate rings, one of which, $\mathrm{MN} 1 \mathrm{C} 2 \mathrm{C} 3 \mathrm{C} 4 \mathrm{O} 1$, is a six-membered and the other, $\mathrm{MN} 1 \mathrm{~N} 2 \mathrm{C} 1 \mathrm{X}(\mathrm{X}=\mathrm{O}, \mathrm{S}, \mathrm{N})$, a five-membered ring. The five-membered chelate rings (FCR) are approximately planar or mildy deformed, whereas with the six-membered chelate rings (SCR), significant conformational differences can be observed. Namely, in some cases $(\mathbf{2 4}, \mathbf{2 5}, 26$ and 27), the SCR has an approximately planar or close to planar conformation $(13,15,16,17,19,26,28,29,30)$, whereas in some complexes $(7,10,11$, 
$\mathbf{1 2}, \mathbf{2 1}, \mathbf{2 2}, \mathbf{2 3}, \mathbf{3 1}$ ), it deviates significantly from a planar conformation. It is very difficult to establish a regularity in the occurrence of SCR planarity, but it should be noticed that the most planar SCR forms are observed in the complexes with PLITSC ligand. Also, it is possible to observe that deformation from the planar form occurs primarily because of rotation around the $\mathrm{O} 1-\mathrm{M}$ bond and partly because of rotation around the $\mathrm{C} 3-\mathrm{C} 2$ bond (exhibiting a very weak character of $\pi$ bond), which is indicated by the values of the $\mathrm{T} 3$ and $\mathrm{T} 5$ torsion angles (Table II). On the other hand, the $\mathrm{O} 1-\mathrm{C} 4-\mathrm{C} 3-\mathrm{C} 2$ fragment is planar in all strctures, which can be seen from the value of the torsion angle T2 (Table II); the latter rarely exceeds $6^{\circ}$, even with very deformed SCR. The SCR conformation has a very important effect on the overall molecule conformation because it brings the pyridine part of the ligand to a position which deviates significantly from the coordination plane formed by the chelate PL ligand, which is seen in Fig. 8 as the deviation of the PLTSC ligand from the broken line representing the ideal equatorial plane. The molecular structure of $\mathbf{3 0}$, which represents an example of the complexes in which the SCR is almost planar, with small values of the T3 and T5 torsion angles is shown in Fig. 7. In the SCR, the N1-N2-Cl-X fragment is almost planar, which is evident from the value of the torsion angle T4. A significant consequence of the ONX coordination of PL ligand and the formation of two fused chelate rings is the deformation of the $\mathrm{O} 1-\mathrm{M}-\mathrm{N} 1, \mathrm{~N} 1-\mathrm{M}-\mathrm{S}$ and $\mathrm{N} 1-\mathrm{M}-\mathrm{N} 4$ coordination angles, which deviate significantly from $90^{\circ}$. The most pronounced deformation of the coordination angles is observed with the structures 6, 21, 27, 30 and 21, in which the $\mathrm{M}-\mathrm{N} 1$ bond is also significantly longer than the $\mathrm{M}-\mathrm{O} 1$ bond, which is not the case with the majority of the other crystalline structures.

TABLE II. Selected bond angles $\left(^{\circ}\right)$ and torsion angles $\left(^{\circ}\right)$ for all crystal structures of the PLTSC, PLITSC and PLSC compounds $(\mathrm{T} 1=\mathrm{O} 2-\mathrm{C} 9-\mathrm{C} 8-\mathrm{C} 3, \mathrm{~T} 2=\mathrm{O} 1-\mathrm{C} 4-\mathrm{C} 3-\mathrm{C} 2, \mathrm{~T} 3=\mathrm{N} 1-\mathrm{C} 2-\mathrm{C} 3-\mathrm{C}-4, \mathrm{~T} 4$ $=\mathrm{N} 1-\mathrm{N} 2-\mathrm{Cl}-\mathrm{X}, \mathrm{T} 5=\mathrm{C} 4-\mathrm{O} 1-\mathrm{M}-\mathrm{N} 1)$

\begin{tabular}{ccccccccc}
\hline Comp. & O1-M-N1 N1-M-X & T1 & T2 & T3 & T4 & T5 & Ref. \\
\hline $\mathbf{1}$ & - & - & 174.4 & -1.2 & -176.8 & -178.0 & - & 25 \\
$\mathbf{2}$ & - & - & -78.0 & -2.4 & 4.8 & -6.3 & - & 31 \\
$\mathbf{3}$ & - & - & 83.6 & -1.2 & 153.5 & -173.1 & - & 30 \\
$\mathbf{4}$ & - & - & -105.8 & -0.0 & 0.5 & 4.6 & - & 30 \\
$\mathbf{5}$ & - & - & 175.6 & 0.5 & 1.7 & 1.6 & - & 28 \\
$\mathbf{6}$ & 80.7 & 78.4 & -49.3 & 5.9 & -11.1 & 3.0 & -25.3 & 54 \\
$\mathbf{7}$ & 86.8 & 83.3 & 173.6 & 0.0 & 16.0 & -0.9 & 43.9 & 48 \\
$\mathbf{8}$ & - & 84,1 & -167.9 & 5.0 & -40.2 & -1.3 & - & 31 \\
$\mathbf{9}$ & - & - & 71.5 & -1.0 & -3.3 & -3.6 & - & 36
\end{tabular}


TABLE II. Continued.

\begin{tabular}{|c|c|c|c|c|c|c|c|c|}
\hline Comp. & $\mathrm{O} 1-\mathrm{M}-\mathrm{N} 1$ & N1-M-X & $\mathrm{T} 1$ & $\mathrm{~T} 2$ & $\mathrm{~T} 3$ & $\mathrm{~T} 4$ & $\mathrm{~T} 5$ & Ref. \\
\hline \multirow[t]{2}{*}{10} & 94.3 & 85.3 & 67.0 & 1.4 & 14.8 & -5.0 & 30.9 & 60 \\
\hline & 93.2 & 85.9 & 64.6 & 1.4 & 16.3 & -2.7 & 34.6 & \\
\hline \multirow[t]{2}{*}{11} & 93.8 & 85.1 & -64.2 & 2.2 & -16.3 & 2.1 & -29.7 & 60 \\
\hline & 93.0 & 85.2 & -64.0 & -2.4 & -21.7 & 6.0 & -38.6 & \\
\hline \multirow[t]{2}{*}{12} & 93.4 & 88.0 & -63.6 & 3.6 & 8.4 & 2.8 & 20.0 & 61 \\
\hline & 93.9 & 86.7 & 61.4 & 2.8 & 11.1 & 1.5 & 26.4 & \\
\hline 13 & 90.8 & 87.4 & -66.4 & 1.2 & 2.0 & 1.8 & 10.0 & 51 \\
\hline 14 & 91.0 & 86.4 & 47.6 & -2.8 & 7.2 & -1.0 & 11.6 & 50 \\
\hline 15 & 94.5 & 86.3 & 174.8 & -0.9 & -6.5 & 1.8 & 10.6 & 54 \\
\hline 16 & 94.3 & 86.7 & 174.9 & -0.2 & -4.0 & -0.5 & -11.0 & 53 \\
\hline 17 & 92.9 & 85.8 & 60.0 & 1.5 & 0.7 & -1.5 & 1.9 & 37 \\
\hline 18 & 92.5 & 85.8 & -63.1 & -1.9 & -8.2 & 1.1 & -18.4 & 37 \\
\hline 19 & 91.4 & 86.7 & 62.1 & 2.3 & 3.8 & 1.8 & 11.3 & 37 \\
\hline 20 & - & - & - & - & - & - & - & 48 \\
\hline 21 & 82.8 & 79,8 & 61.4 & -7.4 & -5.5 & 1.2 & -22.8 & 67 \\
\hline \multirow[t]{2}{*}{22} & 93.2 & 85.2 & -67.1 & -1.0 & -15.8 & 5.7 & -30.9 & 28 \\
\hline & 93.3 & 84.3 & -64.6 & 2.1 & -15.5 & 2.9 & -32.4 & 70 \\
\hline \multirow[t]{2}{*}{23} & 94.1 & 86.1 & 175.3 & 3.4 & 8.7 & -0.8 & 22.1 & 28 \\
\hline & 93.0 & 87.0 & -162.3 & -2.6 & 9.3 & 8.5 & 10.4 & \\
\hline 24 & 91.5 & 81.4 & -66.1 & 1.7 & 1.6 & -179.3 & 3.8 & 26 \\
\hline \multirow[t]{2}{*}{25} & 92.5 & 81.0 & -70.6 & -8.5 & 3.7 & 4.9 & 2.6 & 28 \\
\hline & 93.0 & 80.2 & 66.8 & -5.1 & 2.8 & 7.3 & 7.5 & 53 \\
\hline \multirow[t]{2}{*}{26} & 95.2 & 81.2 & 62.7 & 0.4 & -7.8 & -0.8 & -11.1 & 56 \\
\hline & 95.1 & 82.1 & 177.4 & 5.1 & -3.8 & 1.7 & -1.6 & \\
\hline 27 & 82.3 & 74.1 & -178.3 & -6.6 & 2.3 & 0.0 & -1.7 & 56 \\
\hline 28 & 89.8 & 80.2 & -80.8 & -0.7 & -2.9 & 1.8 & -11.5 & 52 \\
\hline 29 & 92.2 & 82.2 & 76.1 & -0.3 & -3.8 & 3.0 & -12.6 & 56 \\
\hline 30 & 84.2 & 75.9 & 178.7 & -2.5 & -0.6 & 3.1 & 7.4 & 65 \\
\hline 31 & 81.8 & 75.0 & 60.1 & -6.8 & -5.1 & 2.5 & -21.5 & 66 \\
\hline
\end{tabular}

For the complex $\mathbf{2 0}$ the necessary data were unavailable 

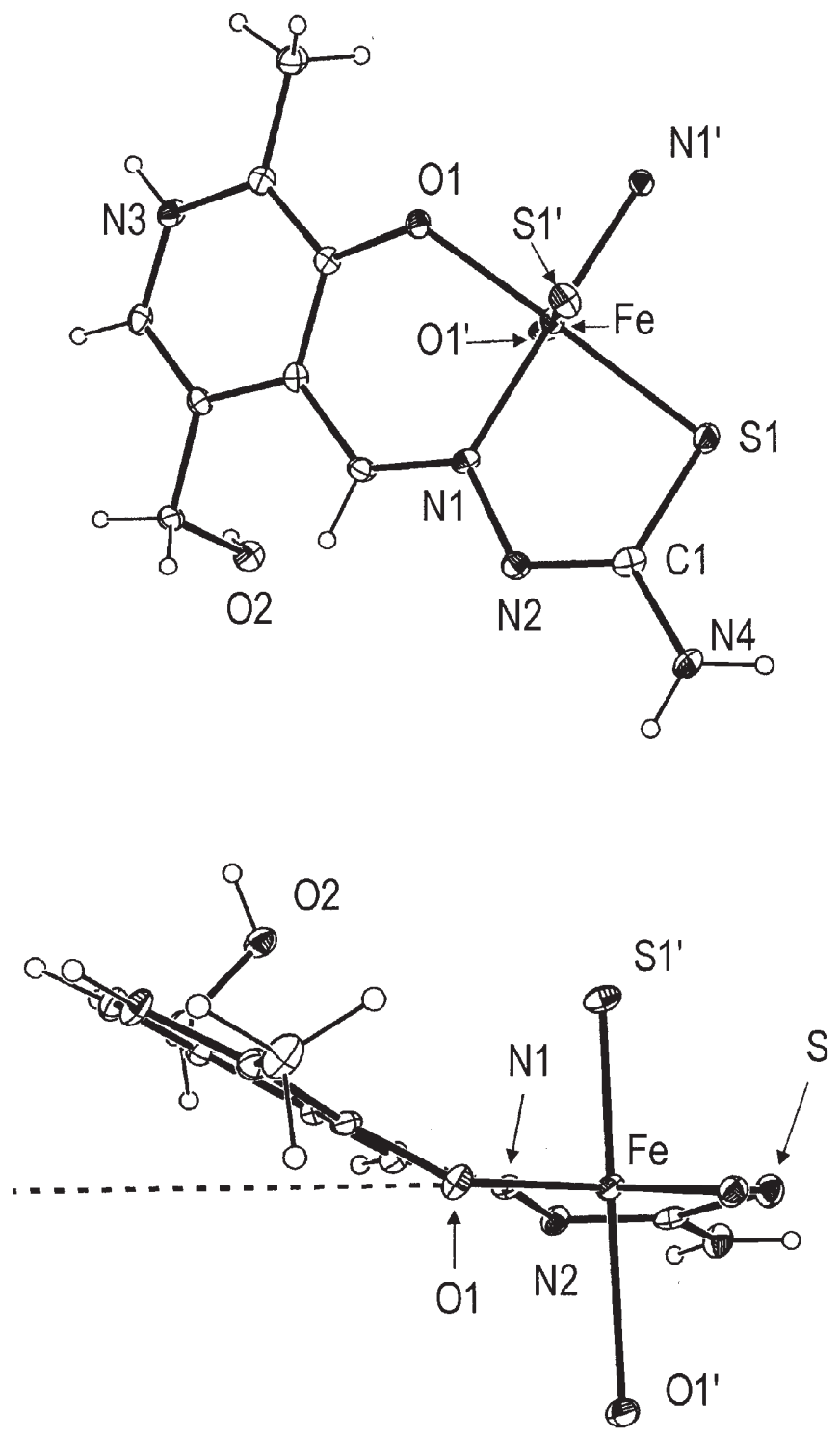

Fig. 8. Fragment of the molecular geometry of complex 22 in two orthogonal projections representing the displacement of the PLTSC ligand from the equatorial coordination plane (dashed line).

In respect to the formation of hydrogen bonds and the occurence of intermolecular interactions, the complexes exhibit different behavior depending on the number of groups that can act as acceptors or donors of hydrogen atoms and their mutual ratio, i.e., the number of potential donors and potential acceptors of $\mathrm{H}$ atoms. Some of the complexes, such as, for example, 13, form 3D supramolecular structures. With this complex, the pyridine ring participates in the formation of 
intermolecular $\mathrm{C}-\mathrm{H} . . . \pi$ interactions, which can also be observed in the complexes $\mathbf{6}, \mathbf{1 0}, \mathbf{1 4}, \mathbf{2 1}, \mathbf{2 8}, \mathbf{3 0}$, and $\mathbf{3 1}$. The N2, N4, N3 and $\mathrm{O} 2$ atoms, are of special importance in the formation of intermolecular hydrogen bonds. As already mentioned, the position of the $-\mathrm{CH}_{2}-\mathrm{O} 2 \mathrm{H}$ fragment with respect to the rest of the ligand is determined exactly by the hydrogen bonds formed with the $\mathrm{O} 2$ atom.

Some of the copper complexes exhibit interesting structural behavior. Namely, the molecules of these complexes form centrosymmetric dimers, but in different ways, i.e., the bonds between the two molecules may be of different strength and involve different atoms. Thus, in the case of complex 18, the coordinated $\mathrm{Cl}$ atom plays the role of a bridging ligand, forming an elongated $\mathrm{Cu}-\mathrm{Cl}$ bond of 2.853 (1) $\AA$ with an adjacent molecule. In the case of complex 19, a centrosymmetric dimer is formed thanks to the formation of a bond between the $\mathrm{O} 2$ and $\mathrm{Cu}$ from the neighboring molecule, the length of which is 2.350(5) $\AA$. In this way, with both of these two complexes, a (4+1) coordination is formed around $\mathrm{Cu}$ and the bond between the molecules in the dimer is strong, which can be concluded on the basis of the mentioned $\mathrm{Cu}$... $\mathrm{Cl}$ and $\mathrm{Cu}$...O2 distances. The formation of dimers in the case of copper complexes 15, 16 and $\mathbf{2 5}$ occurs in a different way, namely dimers are formed by participation of the coordinated atoms from the PL derivatives which enter into interaction with the $\mathrm{Cu}$ atom from a neigboring molecule. Thus, with $\mathbf{1 5}$ and $\mathbf{1 6}$, the coordinated sulfur atom also interacts with a neigboring $\mathrm{Cu}$ atom, occupying approximately the apical position, with a $\mathrm{Cu}$...S distance of 3.066(2) $\AA$ and 3.042(2) $\AA$, respectively. With complex 25 (Fig. 6), as with 15 and 16, the $\mathrm{N} 4$ atom from the PL derivative, which participates in coordination, is also involved in an interaction with the $\mathrm{Cu}$ atom from the other half of the dimer, occupying also the apical position, with $\mathrm{Cu}$... N distances of 3.085(6) and 3.030(6) $\AA$, respectively, in the crystallographically independent units. Although the distances $\mathrm{Cu} . . . \mathrm{S}$ and $\mathrm{Cu} \ldots \mathrm{N} 4$ in 15, 16 and $\mathbf{2 5}$ are significantly longer than the $\mathrm{Cu} . . \mathrm{Cl}$ and $\mathrm{Cu} . . . \mathrm{O} 2$ distances in $\mathbf{1 8}$ and 19, it is still possible to speak of a strong interaction in these dimers too. Also, such dimeric interactions, with $\mathrm{Cu}$..X $(\mathrm{X}=\mathrm{F}, \mathrm{C}, \mathrm{N}, \mathrm{O}, \mathrm{S}, \mathrm{Cl})$ distances which are longer than $2.8 \AA$, are also found in the case of $\mathrm{Cu}$ complexes with other ligands (more than 500 examples), for which it is possible to postulate a formal existence of the square-pyramidal $(4+1)$ configuration. ${ }^{53}$

\section{SPECTRAL CHARACTERISTICS}

\subsection{IR Spectra}

Practically all the ligands and complexes of PLTSC and its derivatives have been characterized in detail, whereas those of PLITSC and PLSC only in part, by recording their IR spectra. A common feature of all these spectra is that in the high-energy, range, i.e., between 3500 and $3100 \mathrm{~cm}^{-1}$ they possess several bands which are ascribed to the $v(\mathrm{OH})$ vibration of hydroxymethyl group and $\mathrm{H}_{2} \mathrm{O}$, along with $v\left(\mathrm{NH}_{2}\right)$ vibrations. The $v(\mathrm{NH})$ band, which in the spectra of free PLSC and PLTSC is observed at about 3150 
$\mathrm{cm}^{-1} 25,28,55$ is missing from the spectra of singly-deprotonated ligands. This also holds for the $v\left(\mathrm{NH}^{+}\right)$band from the pyridine ring, which in the spectra of the free ligands and complexes involving monoanionic ligands is observed at about $2850 \mathrm{~cm}^{-1}$, while it is also absent from the spectra of complexes with the dianionic form of the ligand. The very strong $v(\mathrm{C}=\mathrm{O})$ band in PLSC ligand at $1680 \mathrm{~cm}^{-1}, 27$ i.e., around the value characteristic for the majority of semicarbazones, ${ }^{71,72}$ is in the complexes shifted to lower energies by $15-20 \mathrm{~cm}^{-1}$ (neutral form), or is lost (anionic form). A number of bands in the range $1640-1400 \mathrm{~cm}^{-1}$ in the spectra of both ligands and complexes are ascribed to pyridoxal ring vibrations, as well as to the $v(\mathrm{C}=\mathrm{N})$ and $\delta\left(\mathrm{NH}_{2}\right)$ of the chain. ${ }^{25,28,55} \mathrm{M}$. Belicchi Ferrari et al. ${ }^{50}$ observed that in the complexes involving neutral and singly-deprotonated form of the PLTSC ligand, such as $\left[\mathrm{Cu}(\mathrm{PLTSC}) \mathrm{Cl}\left(\mathrm{H}_{2} \mathrm{O}\right)\right] \mathrm{Cl}$ and $\left[\mathrm{Cu}(\mathrm{PLTSC}-\mathrm{H}) \mathrm{H}_{2} \mathrm{O}\right] \mathrm{Cl}$, spectral changes occur in the $1500-1400 \mathrm{~cm}^{-1}$ region upon deprotonation of the TSC fragment. Namely, the spectra of PLTSC complexes in this region are characterized by four medium-intensity bands which can be mainly ascribed to the pyridoxal ring, in contrast to the spectrum of the complex with PLTSC-H, which in this range has three bands. The authors think that this reduction in the number of bands in the given region is a consequence of the electronic delocalization occuring after deprotonation. A similar trend has also been observed in the case of Co(III) complex with this ligand. ${ }^{60}$ The medium-intensity $v(\mathrm{C}=\mathrm{S})$ band in the ligand PLTSC and its substituted derivatives, observed in the range of $c a .990-840 \mathrm{~cm}^{-1}$ is shifted due to complexation by $c a .20-100 \mathrm{~cm}^{-1} \cdot 25,37,69$ Nevertheles, the $v(\mathrm{SH})$ band (at $c a .2 .500 \mathrm{~cm}^{-1}$ ) is missing from the spectra of these ligands, so that it can be concluded that, as with the other TSCs, the thioketo form is also predominant in the crystal of this thiosemicarbazone.

\subsection{Electronic spectra}

The spectra of numerous transition metal complexes containing different types of thiosemi- or semicarbazone-based ligands have been described in the literature. ${ }^{1}$ The obtained spectra display all kinds of electronic transitions characteristic of ligands and metal ions in coordination. This has been clearly illustrated in several papers on Fe(III) complexes with salicylaldehyde thiosemi-, isothiosemi- and semicarbazones. These spectra are sensitive to the type of ligand species involved in coordination (i.e., $\mathrm{L}, \mathrm{L}-\mathrm{H}, \mathrm{L}-2 \mathrm{H})^{73,74}$ and also to the influence of ions present in the DMF solutions $\left(\mathrm{Cl}^{-}, \mathrm{H}^{+}\right.$, etc. $)$. Therefore, the appearance of a spectrum has proved to be a useful support in the identification of particular complex species. In addition, a method for the spectrophotometric monitoring of the course of protonation of Fe(III) complexes alone $\mathrm{e}^{75,76}$ and in binary mixtures ${ }^{77}$ was successfully developed.

Contrary to this, the electronic spectral data for the title compounds has been reported in only a few papers.

Studies of the acid-base equilibria of different ligand species ${ }^{25}$ in aqueous solutions of different $\mathrm{pH}$ and of several $\mathrm{N}$-substituted PLTSC derivatives ${ }^{30}$ have re- 
cently been reported. The experimental absorbance values were compared to the calculated ones and the $\mathrm{pH}$ range in which a particular species is stable was determined. The protonation constants of the unsubstituted ligand show three distinct proton transfers to the alcoholic (PLTSC-H) $\left(\log K_{1}=11.11\right)$ and phenolic groups (PLTSC) $\left(\log K_{2}=7.94\right)$ and pyridine nitrogen atom $\left(\mathrm{PLTSC} \cdot \mathrm{H}^{+}\right)\left(\log K_{3}=\right.$ 4.29). ${ }^{25}$ In a subsequent study of substituted PLTSC, the same authors ${ }^{30}$ established the possibility of protonation in total four centers, one more than previously $-i . e$., the hydrazine nitrogen as the third in order. The values of the corresponding $\log K$ are similar to those cited above.

For the N4-substituted PLTSC copper(II) complexes of the formula $[\mathrm{Cu}(\mathrm{PLTSCR}-\mathrm{H}) \mathrm{Cl}] \cdot \mathrm{H}_{2} \mathrm{O}$, the reflectance spectra of powdered samples and the adsorption spectra in $\mathrm{MeOH}$ and DMSO solutions were recorded. ${ }^{55}$ Both techniques showed two main absorption bands of these complexes: the first (at about 630-640 $\mathrm{nm}$ ) being ascribed to d-d transitions, while the other,which is dependent on the solution composition, appears at $385-415 \mathrm{~nm}$. This band is the result of charge transfer $\mathrm{S}$ $\rightarrow \mathrm{Cu}$ transition and its dependence on the solvent is taken as proof that the complex undergoes solvolysis, thus yielding species of the type $[\mathrm{Cu}(\mathrm{PLTSCR}-\mathrm{H})(\mathrm{solv}] \mathrm{Cl}$.

The electronic spectra of the three series of mono- and bis(ligand) Fe(III) complexes containing either, $\mathrm{L}, \mathrm{L}-\mathrm{H}$ or $\mathrm{L}-2 \mathrm{H}$ forms of PLSC, PLTSC and PLITSC were recorded in DMF solutions. ${ }^{62,63}$ Their features were compared with those of the corresponding ligands obtained in the same solvent. Apart from the absorption bands at $\lambda<300 \mathrm{~nm}$, which are mainly a consequence of intraligand transitions and can be observed almost unchanged in the spectra of PLTSC or PLTSC-H-containing complexes, the other bands appearing in the region of $300-450 \mathrm{~nm}$ are rather different in the complexes from those of the pure ligands. In fact, the bands are composed of contributions of several close (intraligand and charge-transfer) processes which seem to be overlapped. The most complex spectra were recorded for non-electrolyte compounds (i.e., $[\mathrm{Fe}(\mathrm{L}-\mathrm{H})(\mathrm{L}-2 \mathrm{H})]$ ) because of the absorption of the $\mathrm{L}-2 \mathrm{H}$ species. Common characteristics of all spectra (the only exception being the low-spin Fe(III) complex) is the absence of bands which could be ascribed to d-d transitions. In addition, in order to support findings of cyclic voltametric experiments, the authors also recorded spectra in DMF containing $\mathrm{LiCl}$ and/or $\mathrm{H}^{+}$. The results were useful for explaining the stability of particular complex species in solutions.

\subsection{Other techniques}

Apart from these spectral techniques (IR and UV-vis), some diamagnetic complexes of $\mathrm{Sn}(\mathrm{IV}),{ }^{58} \mathrm{Tl}(\mathrm{III}),{ }^{36} \mathrm{Au}(\mathrm{III}),{ }^{31}$ and $\mathrm{Pt}(\mathrm{IV}),{ }^{27}$ as well as the corresponding ligands, have also been characterized by NMR spectroscopy. In addition, Sn complexes, ${ }^{58}$ along with some Fe complexes have also been characterized by Mössbauer spectroscopy too. ${ }^{29,69}$ Finally, EPR characterizations of some Fe and $\mathrm{Cu}$ complexes have also been reported. 55,69 


\section{ELECTROCHEMISTRY}

In order to characterize the redox processes which may occur on the ligands and complexes, as well as to examine the stability of complex species in solution, electrochemical investigations in suitable solvents are usually performed. Although the TSC-based ligands and their complexes were the subject of many polarographic and voltammetric studies, ${ }^{78,79}$ the title Schiff bases and their complexes have only been described in a few articles. Furthermore, although there are several reports on the electrochemical (in particular, polarographic) behavior of PL alone, ${ }^{80,81}$ no data were found on its condensation products with semi- or thiosemicarbazide. On the basis of the analogy of the structures of the studied new Schiff-base ligands and those described previously with salicylaldehyde condensation products, ${ }^{82,83}$ it could be supposed that the new ligands and, consequently, their complexes can be more easily reduced, which was confirmed in some cases.

Detailed voltammetric studies have been concerned with the electrochemical behavior of a number of $\mathrm{Fe}$ (III) complexes of different types (mono- and bis(ligand), using $\mathrm{L}, \mathrm{L}-\mathrm{H}$ or $\mathrm{L}-2 \mathrm{H}$ species) with all three ligands. ${ }^{62,63}$ These complexes were investigated in DMF, in the presence of several supporting electrolytes, at a glassy carbon working electrode.

The complexity of the behavior of these complexes is clearly seen from Fig. 9 giving the cyclic voltammograms of a non-electrolyte complex, which is more stable than the other types of complexes, recorded in an inert medium. This complex in DMF behaves as a coordination dimer of the type $\left[\mathrm{Fe}(\mathrm{L}-\mathrm{H})_{2}\right]\left[\mathrm{Fe}(\mathrm{L}-2 \mathrm{H})_{2}\right]$. The complex species undergo several reduction and oxidation processes. First two electronation processes (down to $-1.0 \mathrm{~V}$ ) are centered on $\mathrm{Fe}(\mathrm{III})$, while the other three are located on

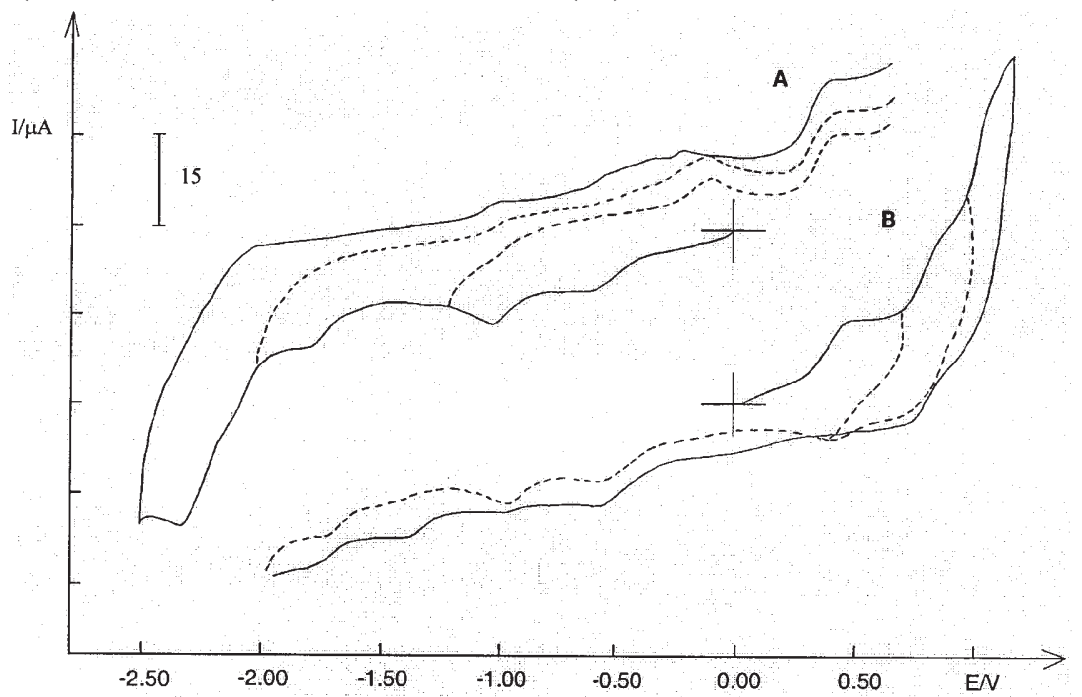

Fig. 9. Cyclic voltammograms for $[\mathrm{Fe}(\mathrm{PLSC}-\mathrm{H})(\mathrm{PLSC}-2 \mathrm{H})]$ in $0.1 \mathrm{~mol} \mathrm{dm}^{-3} \mathrm{TBAP} / \mathrm{DMF}$ obtained at a $\mathrm{GC}$ electrode $\left(0.20 \mathrm{~V} \mathrm{~s}^{-1}\right)$ : reduction processes (A) and oxidation processes (B). 
the ligand moieties (about $-2 \mathrm{~V}$ ). Most of the processes are followed by chemical reactions, usually irreversible; the reactions being faster if the medium contained "attractive" species such as $\mathrm{Cl}^{-}$for the $\mathrm{Fe}(\mathrm{III}) / \mathrm{Fe}(\mathrm{II})$ pair, or $\mathrm{H}^{+}$and $\mathrm{Li}^{+}$for the ligands. The oxidations are similar to those described below: 55 in perchlorate medium, the processes taking place in the range of ligand oxidation $(>+0.5 \mathrm{~V})$ are followed by fast irreversible chemical rections of complex decomposition. In all solutions, the established readiness to undergo corresponding reduction/oxidation process for the same type of complexes can be attributed to the coordinated donor set of atoms: ONS $>\mathrm{ONO} \sim \mathrm{ONN}$, which is in accordance with previous reports on similar complexes with thiosemi-, isothiosemi- and semicarbazone-based ligands condensed with salicylaldehyde (instead of PL). ${ }^{82,83}$

The $\mathrm{Cu}(\mathrm{II})$ complex with pyridoxal N4-substituted thiosemicarbazone $[\mathrm{Cu}(\mathrm{PLTSCEt}-\mathrm{H}) \mathrm{Cl}] \cdot \mathrm{H}_{2} \mathrm{O}$, was investigated in $\mathrm{MeOH}$ at a platinum electrode. ${ }^{55} \mathrm{It}$ exhibits three one-electron processes: one for reduction $(-0.28 \mathrm{~V})$ and two for oxidation $(+0.52 \mathrm{~V}$ and $+0.98 \mathrm{~V})$. The reduction and first oxidation processes are reversible, the latter being followed by a slow chemical reaction of complex decomposition. The reduction/oxidation tendency proves that the presence of substitutents on the ligand has no effect on the electric charge of the donor atoms (ONS). Consequently, this facility is mainly due to the presence of the sulfur atom, as is to be expected on the basis of many data reported previously for similar ligands.

\section{BIOLOGICAL ACTIVITY}

One of the main reasons why the literature concerning thiosemicarbazones is richer and more diverse than that of the semicarbazones is the higher biological activity of the former. Since the pioneering work of Domagk et al. ${ }^{84}$ in 1946 on the antituberculosis activity of $p$-acetamidobenzaldehyde thiosemicarbazone (trivial names Thiacetazone or Tibon), the number of papers concerning the pharmacological use of these compounds has dramatically increased, due to the wide spectrum of their biological activity found in recent years. ${ }^{9,85}$ Nowadays, it is known that thiosemicarbazones show antitumorous, antiviral, antifungal, antibacterial and antimalarial activities. Of course, the primary task of researches is to investigate new compounds in respect of their activity against tumors and viruses. A correlation between the structure and biological activity has been established, ${ }^{3}$ the tridentate NNS 2-(N)-heterocyclic thiosemicarbazones being apparently most efficient as therapeutic agents. A new example of a potentially successful Fe(III) chelator in treating iron overload diseases is 3-aminopyridine-2-carboxaldehyde thiosemicarbazone $\left(\right.$ Triapine $^{\circledR}$ ), which has recently entered clinical trials. ${ }^{86,87}$ Of course, not only the ligands were found to be useful in pharmacological applications. It has been repeatedly shown that compared to the ligands, the thiosemicarbazone-based metal complexes (for example, $\mathrm{Cu}$ and $\mathrm{Zn}$ ) are more efficient inhibitors of cancer cell growth. ${ }^{88}$ 
As mentioned above, semicarbazones have a rather limited biological activity spectrum. 9,85 They are mainly used as anticonvulsants, anti-protozoa agents, radioprotectors or radio-pharmaceuticals. There are also several reports on their anti-leukemia activity in mice, ${ }^{5}$ as well as on antimicrobial ${ }^{89}$ and pesticide effects, ${ }^{90}$ etc.

Until recently, it was assumed that isothiosemicarbazones are biologically inactive. However, Italian authors ${ }^{91-93}$ found a good antimicrobial potential for some of a range of 78 tested compounds, of which the 5-nitrofuryl derivative proved to be the most efficient.

Among an ample variety of tiosemicarbazone derivatives and their metal complexes, only a few examples of biological (including antiproliferative) tests with pyridoxal-based ligands can be found in the literature. One of the very promising applications of these compounds, such as pyridoxal aroylhydrazone, is their use as iron(III) chelating ligands in treating diseases of iron overload. ${ }^{94,95}$ For this purpose, Darnell and Richardson, after testing a number of compounds of this class, identified the most efficient molecule. ${ }^{96}$ They found 2-hydroxy-1-napthylaldehyide isonicotinoyl hydrazone is more effective in intracellular Fe chelation than desferrioxamine, the ligand of choice so far, being thus capable of antiproliferative action in some tumors. A study of this and similar aroylhydrazone compounds in vivo is now in progress. ${ }^{86}$

However, as far as the biological activities of ligands based on PLTSC or PLSC and their complexes are concerned, there are only a few reports. The group of Belicchi Ferrari made a major contribution to these studies with their in vitro investigations of the activities of copper(II) compounds.

The ligand PLTSC and its copper(II) complexes - the monomeric $\left[\mathrm{Cu}(\mathrm{PLTSC})\left(\mathrm{H}_{2} \mathrm{O}\right) \mathrm{Cl}\right] \mathrm{Cl}$ and dimeric $\left[\mathrm{Cu}(\mathrm{PLTSC}-\mathrm{H})\left(\mathrm{H}_{2} \mathrm{O}\right)\right]_{2} \mathrm{Cl}_{2} \cdot 2 \mathrm{H}_{2} \mathrm{O}$, as well as the cobalt(III) complex, [Co(PLTSC-H)(PLTSC-2H)] $4.5 \mathrm{H}_{2} \mathrm{O}$ were tested in respect of their biological activity. The obtained results showed that the $\mathrm{Cu}(\mathrm{II})$ complexes do not have antiviral action in vitro against RNA viruses, exhibit an inductive effect on Friend erythroleukemia cells (FLC), erythroid differentiation, and have a suppressive effect regarding FLC proliferation. In contrast to this, the cobalt(III) complex and free ligand showed no biological activity. The authors ascribe the observed differences in biological activities to the nature of the active species: $\left[\mathrm{Cu}(\mathrm{PLTSC})\left(\mathrm{H}_{2} \mathrm{O}\right)\right]^{2+}$ in the monomeric and $\left[\mathrm{Cu}(\mathrm{PLTSC}-\mathrm{H})\left(\mathrm{H}_{2} \mathrm{O}\right)\right]^{+}$in the dimeric complex, while the completely saturated coordination sphere in the octahedral Co(III) complex could be the reason for its lack of reactivity. Also, the free ligand PLTSC has no influence on FLC differentiation and other tests, probably due to its intramolecular hydrogen bonding, which is different from that in the complexes. 50

The ligands PLTSCEt and PLTSCMe $\mathrm{H}_{2} \cdot \mathrm{H}_{2} \mathrm{O}$ (PLTSCEt/Me $\mathrm{Me}_{2}=$ pyridoxal N4-ethyl/dimethylthiosemicarbazone) have been tested in vitro against the U937 human 
leukemic cell lines. Studies involving both inhibition of cell proliferation and apoptosis test showed that both ligands inhibited cell growth, but neither of them induced apoptosis. ${ }^{30}$

The above unsubstituted ligand and its $\mathrm{Cu}$ (II) dimeric complex ${ }^{50}$ were tested along with new copper dimeric complexes with $\mathrm{N} 4$-alkylated pyridoxal thiosemicarbazones of the formulas: $\mathrm{Cu}\left(\mathrm{PLTSCMe}_{2}-\mathrm{H}\right) \mathrm{Cl}_{2} \cdot 6 \mathrm{H}_{2} \mathrm{O}$ and $\left[\mathrm{Cu}(\mathrm{PLTSCEt}) \mathrm{Cl}_{2} \mathrm{Cl}_{2} \cdot 2 \mathrm{H}_{2} \mathrm{O}\right.$ and $\mathrm{N} 2$,N4-methylated derivative $\left[\mathrm{Cu}(\mathrm{PLTSCMeMe}) \mathrm{Cl}_{2} \mathrm{Cl}_{2} \cdot 4 \mathrm{H}_{2} \mathrm{O} .{ }^{37}\right.$ The previously synthesized compounds were applied on different murine and human leukemic cell lines both in vitro and in vivo and their activities were compared to the activity of the corresponding monomeric complex. Both complexes showed significant inhibition of TS/A murine adenocarcinoma cell proliferation in vitro, but they lacked in vivo activity of TLX5 lymphoma. Also, apoptosis on CEM and U937 human cell lines could be induced and their cycle altered with the dimeric complex. In comparison with this compound, the new complexes with $\mathrm{N}$-alkylated ligands exerted only weak or practically no effect on the same cell lines (U937, CEM and K562), which is in accordance with previous reports on the effect of a substituent present on the amine nitrogen. ${ }^{97}$

The biological activity of organotin(IV) complexes with PLTSC of the formula $\left[\mathrm{SnR}_{2}(\mathrm{PLTSC}-2 \mathrm{H})\right](\mathrm{R}=\mathrm{Me}, \mathrm{Et}, \mathrm{Bu}, \mathrm{Ph})$ was also evaluated. ${ }^{58}$ With the exception of the Me-complex, the other three suppress FLC proliferation, with the lowest thresholds for the latter two compounds. In contrast to the copper monomeric complexes with PLTSC, 50 the tin complexes did not enhance DMSO-induced FLC differentation.

\section{OTHER CHARACTERISTICS}

Apart from their biological activity which can be used for pharmacological purposes, the title ligands and certain complexes appeared to be sensitive analytical tools for determining traces of metals in several complex materials. On the other hand, in some cases, the in situ formation of the ligand alone in the reaction of its constituent parts can also be exploited for analytical purpose.

Thus, in plasma analyses of vitamin $\mathrm{B}_{6}$ vitamers (PL and PLP), which are very photosensitive, a new HPLC method based on precolumn semicarbazone formation and fluorescence detection has been proposed. ${ }^{98}$ The obtained semicarbazones not only enhanced the fluorescence effects in comparison with the vitamers alone, but also increased their stability, thus enabling quantitative plasma PLP determinations even in $\mathrm{B}_{6}$-deficient patients.

A kinetic spectrophotometric method was used in several cases to determine binary metal ion mixtures with PLTSC, provided the rates of metal ion reaction were sufficiently different. Thus, this method was successfully used to determine iron and cobalt ions in model solutions, ${ }^{99}$ iron and copper in serum samples, ${ }^{100}$ and copper and cobalt in steel samples. ${ }^{101}$ The last method was based on a flow-injection procedure described in a previous work ${ }^{102}$ for the determination of cobalt 
with pyridoxal N4-phenylthiosemicarbazone. The same reagent was successfully used to determine iron(III) in some standard alloys and pharmaceutical samples. ${ }^{103}$

Pyridoxal, N4-methylthiosemicarbazide, pyridoxal N4-methylthiosemicarbazone and $\mathrm{Zn}$ (II)-pyridoxal N4-methylthiosemicarbazone exibited an interesting feature in a study of the inhibition of mild steel corrosion. ${ }^{104}$ The $\mathrm{Zn}$ (II) complex appeared to be the most efficient, even when applied in a highly acidic medium.

\section{CONCLUSION}

Pyridoxal semi-, thiosemi- and isothiosemicarbazones represent a relatively new group of tridentate ONX $(\mathrm{X}=\mathrm{O}, \mathrm{S}, \mathrm{N})$ ligands of the Schiff-base type, exhibiting good complexing properties. Depending primarly on the synthesis conditions, $\mathrm{pH}$, and nature of the metal ion, they can be coordinated either as neutral, mono- or dianionic ligands, whereby the proneness of the semicarbazide moiety to deprotonate increases in the series PLITSC $<$ PLSC $<$ PLTSC. Due to these properties, their tridentate nature and to the similarity of the nature of ligand molecules as a whole, it is not surprising that with the same metal (with a small number of exceptions) they give very similar types of complexes. Some Fe(III) chelates with PLTSC and its derivatives, are of special interest with respect to their magnetic characteristics. Namely, it has been found that the spin state of the central atom in these chelates may depend on both the nature of the substituent in the TSC fragment and the number of crystalline water molecules. Still it should be pointed out that this phenomenon is not a new one, as it was previously observed with $\mathrm{Fe}(\mathrm{III})$ complexes with salicylaldehyde thiosemicarbazone. Several $\mathrm{Fe}(\mathrm{III})$ and $\mathrm{Cu}(\mathrm{II})$ complexes with PLSC, PLTSC and PLITSC were electrochemically studien in non-aqueous media. A rather complicated voltammetric behavior, especially in the case of the $\mathrm{Fe}(\mathrm{III})$ compounds, was reported. Additionally some $\mathrm{Cu}(\mathrm{II})$ and $\mathrm{Sn}(\mathrm{IV})$ complexes with PLTSC and its derivatives showed certain biological activity, suppressing FLC proliferation in vitro, and some PLTSC derivatives have been proposed as sensitive analytical reagents of different transition metal ions.

Acknowledgement: This work was supported by the Ministry of Science and Environmental Protection of the Republic of Serbia (Grant No. 1318). 
И З В О Д

\section{КОМПЛЕКСИ МЕТАЛА СА ШИФОВИМ БАЗАМА, ЛИГАНДИМА НА БАЗИ ДЕРИВАТА СЕМИКАРБАЗИДА И ПИРИДОКСАЛА \\ ВУКАДИН М. ЛЕОВАЦ, ${ }^{1}$ ВИОЛЕТА С. ЈЕВТОВИЋ,${ }^{1}$ ЈИљАНА С. ЈОВАНОВИЋ ${ }^{1}$ и ГОРАН А. БОГДАНОВИЋ ${ }^{2}$}

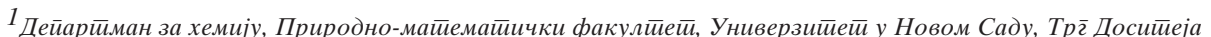
Обрадовића 3, 21000 Нови Сад и ${ }^{2}$ Инсииийуй за нуклеарне науке Винча, Лаборайорија за йеоријску физику и физику кондензоване майерије, $\bar{u} . \bar{u} .522,11001$ Беог̄рад
}

Приказани су најважнији резултати опсежних испитивања (синтезе, спектралне, магнетне, волтаметријске и структурне карактеристике и биолошка активност) комплекса различитих метала са семи-, тиосеми- и изотиосемикарбазонима пиридоксала.

(Примљено 23. децембра 2004)

\section{REFERENCES}

1. M. J. M. Campbell, Coord .Chem. Rev. 15 (1975) 279

2. S. Padhye, G. B. Kauffman, Coord. Chem. Rev. 63 (1985) 127

3. D. X. West, S. B. Padhye, P. B. Sonawane, Struct. Bond. 76 (1991) 1

4. D. X. West, A. E. Liberta, S. B. Padhye, R. C. Chikate, P. B. Sonawane, A. S. Kumbhar, R. G. Yerande, Coord. Chem. Rev. 123 (1993) 49

5. S. N. Pandeya, J. R. Dimmock, Pharmazie 48 (1993) 659

6. J. S. Casas, M. S. Garcia-Tasende, J. Sordo, Coord. Chem. Rev. 209 (2000) 197

7. R. B. Singh, B. S. Garg, R.P. Singh, Talanta 25 (1978) 619

8. V. Arion, M. Revenko, J. Gradinaru, Yu. Simonov, V. Kravtsov, N. Gerbeleu, E. Saint-Aman, F. Adams, Rev. Inorg. Chem. 21 (2001) 1

9. H. Beraldo, Quim. Nova 27 (2004) 461

10. V. M. Leovac, V. I. Češljević, Coordination Chemistry of Isothiosemicarbazide and It's Derivatives, Faculty of Science, Novi Sad, 2002 (in Serbian)

11. S. Chandra, X. Sangeetika, Spectrochim. Acta (A) 60 (2004) 147

12. N. K. Singh, A. Srivastava, A. Sodhi, P. Ranjan, Trans. Met. Chem. 25 (2000) 133

13. N. V. Gerbeleu, V. B. Arion, J. Burgess, Template Synthesis of Macrocyclic Compounds, Wiley-VCH, Weinheim, 1999

14. V. M. Leovac, Lj. S. Jovanović, V. I. Češljević, L. J. Bjelica, N. J. Ević, Polyhedron 11 (1992) 1029

15. U. Knof, T. Weyhermuller, T. Wolter, K. Weighardt, J. Chem. Soc. Chem. Commun. (1993) 726

16. V. I. Češljević, V. M. Leovac, J. Serb. Chem. Soc. 59 (1994) 13

17. V. Arion, K. Weighardt, T. Weyhermuller, E. Bill, V. M. Leovac, A. Rufinska, Inorg. Chem. 36 (1997) 661

18. R. H. Holm, Complexes of Vitamin $B_{6}$ in Inorganic Biochemistry, G. B. Eichhorn, Ed., Elsevier, Amsterdam, 1975.

19. A. G. Sykes, R. D. Larsen, J. R. Fisher, E. H. Abott, Inorg. Chem. 30 (1991) 2911

20. P. Gili, M. G. Martin Rayes, M. G. Martin Zarza, M. F. C. Guedes da Silva, Y.-Y. Tong, A. J. L. Pombeiro, Inorg. Chim. Acta 255 (1997) 279

21. W. Henderson, L. L. Koh, J. D. Ranford, W. T. Robinson, J. O. Svensson, J. J. Vittal, Yu. M. Wang, Y. Xu, J. Chem. Soc. Dalton Trans. (1999) 3341

22. D. Dolphin, R. Poulson, O. Avramovic, Eds., Vitamin B-6 Pyridoxal Phosphate: Chemical, Biochemical and Medical Aspects, Part A, Wiley, New York, 1986

23. K. Aoki, H. Yamazaki, J. Chem. Soc. Chem. Commun. (1980) 363

24. T. Taguchi, M. Sugiura, Y. Hamada, I. Miwa, Eur. J. Pharmacol. 378 (1999) 283

25. M. Ferrari Belicchi, G. Fava Gasparri, E. Leporati, C. Pelizzi, P. Tarasconi, G. Tosi, J. Chem. Soc. Dalton Trans. (1986) 2455 
26. V. M. Leovac, V. S. Jevtović, G. A. Bogdanović, Acta Cryst. C58 (2002) 514

27. N. Ž. Knežević, V. M. Leovac, V. S. Jevtović, S. Grgurić-Šipka, T. J. Sabo, Inorg. Chem. Commun. 6 (2003) 561

28. V. S. Jevtović, Ph. D. Thesis, Faculty of Science, University of Novi Sad, 2002

29. M. Mohan, P. H. Madhuranath, A. Kumar, M. Kumar, N. K. Jha, Inorg. Chem. 28 (1989) 96

30. M. Belicchi Ferrari, F. Bisceglie, E. Leporati, G. Pelosi, P. Tarasconi, Bull. Chem. Soc. Jpn. 75 (2002) 781

31. U. Abram, K. Ortner, R. Gust, K. Sommer, J. Chem. Soc. Dalton Trans. (2000) 735

32. F. Basuli, M. Ruf, C. G. Pierpont, S. Bhattacharya, Inorg. Chem. 37 (1998) 6113

33. J. S. Casas, E. E. Castellano, A. Macias, M. C. Rodriguez-Argüelles, A. Sánchez, J. Sordo, J. Chem. Soc. Dalton Trans. (1993) 353

34. F. Basuli, S. M. Peng, S. Bhattacharya, Inorg. Chem. 39 (2000) 1120

35. J. S. Casas, M. V. Castano, M. C. Cifuentes, A. Sánchez, J. Sordo, Polyhedron 21 (2002) 1651

36. J. S. Casas, E. E. Castellano, M. C. Rodriguez-Argüelles, A. Sanchez, J. Sordo, J. Zukerman-Schpector, Inorg. Chim. Acta 260 (1997) 183

37. M. Belicchi Ferrari, F. Bisceglie, G. Pelosi, P. Tarasconi, R. Albertini, P. P. Dall' Aglio, S. Pinelli, A. Bergamo, G. Sava, J. Inorg. Biochem. 98 (2004) 301

38. Gy. Argay, A. Kalman, L. Parkanyi, V. M. Leovac, I. D. Brčeski, P. N. Radivojša, J. Coord. Chem. 51 (2000) 9

39. I. G. Santos, U. Abram, R. Alberto, E. V. López, A. Sánchez, Inorg. Chem. 43 (2004) 1834

40. N. C. Kasuga, K. Sekino, C. Koumo, N. Shimada, M. Ishikawa, K. Nomiya, J. Inorg. Biochem. 84 (2001) 55

41. A. Takeuchi, S. Komorita, Chem. Express 3 (1988) 535

42. V. M. Leovac, G. A. Bogdanović, V. I. Češljević, V. Divjaković, Acta Cryst. C56 (2000) 936

43. V. N. Biyushkin, V. I. Gerasimov, I. V. Rozdestvenskaya, Koord. khim. 12 (1986) 1270

44. M. S. El-Ezaby, N. Gayed, J. Inorg. Nucl. Chem. 37 (1975) 1065

45. H. M. Dawes, J. M. Waters, T. N. Waters, Inorg. Chim. Acta 66 (1982) 29

46. V. H. Sabirov, A. S. Batsanov, Yu. T. Strutskov, M. A. Azizov, Koord. khim. 9 (1983) 1701

47. S. Dey, P. Banerjee, S. Gangopadhyay, P. Vojtišek, Transition Met. Chem. 28 (2003) 765

48. M. Belicchi Ferrari, G. Gaspari Fava, C. Pelizzi, P. Tarasconi, J. Chem. Soc. Dalton Trans. (1992) 2153

49. V. S. Jevtović, V. M. Leovac, S. Markov, J. Simeunović, Yucomat 2003. Herceg-Novi, p. 118

50. M. Belicchi Ferrari ,G. Gasparri Fava, C. Pelizzi, P. Tarasconi, R. Albertini, S. Pineli, R. Starchich, J. Inorg. Biochem. 53 (1994) 13

51. M. Belicchi Ferrari, G. Gaspari Fava, C. Pelizzi, G. Pelosi, P. Tarasconi, Inorg. Chim. Acta 269 (1998) 297

52. D. Poleti, Lj. Karanović, V. M. Leovac, V. S. Jevtović, Acta Cryst. C59 (2003) 73

53. G. A. Bogdanović, V. M. Leovac, V. B. Medaković, V. S. Jevtović, S. D. Zarić, 6th International Conference on Fundamental and Applied Aspects of Physical Chemistry, Belgrade 2002, Proceedings, p. 723

54. M. Belicchi Ferrari, G. Gaspari Fava, C. Pelizzi, P. Tarasconi, G. Tosi, J. Chem. Soc. Dalton Trans. (1987) 227

55. M. Mohan, N. S. Gupta, M. Kumar, W. E. Antholine, M. J. Ahmed, N. K. Jha, Trans. Met. Chem. 19 (1994) 265

56. V. M. Leovac, unpublished results

57. A. Symal, M. R. Maurya, Trans. Met. Chem. 11 (1986) 255

58. J. S. Cass, M. C. Rodriguez-Argüelles, U. Russo, A. Sánchez, J. Sordo, A. Vázquez-López, S. Pinelli, P. Lunghi, A. Bonati, R. Albertini, J. Inorg. Biochem. 69 (1998) 283

59. F. Grases, C. Genestar, Radaiochim. Acta 39 (1985) 43

60. M. Belicchi Ferrari, G. Gasparri Fava, M. Lanfranchi, C. Pelizzi, P. Tarasconi, J. Chem. Soc. Dalton Trans. (1991) 1951 
61. M. Belicchi Ferrari, G. Gaspari. Fava, G. Pelizzi, M. C. Rodriguez-Argüelles, P. Tarasconi, J. Chem. Soc. Dalton Trans. (1995) 3035

62. V. S. Jevtović, Lj. S. Jovanović, M. V. Leovac, L.J. Bjelica, J. Serb. Chem. Soc. 68 (2003) 929

63. Lj. S. Jovanović, V. S. Jevtović, V. M. Leovac, L. J. Bjelica, J. Serb. Chem. Soc. 70 (2005) 187

64. M. Belicchi Ferrari, G. Gaspari Fava, S. Pinelli ,C.Pelizzi, P. Tarasconi, $6^{\text {th }}$ Yugoslav-Italian Crystallgoraphic Conference, Pula, 1989, Abstracts, p. 23

65. V. S. Jevtović, Z. K. Jaćimović, Z. D. Tomić, G. Giester, V. M. Leovac, 41. Savetovanje Srpskog hemijskog društva, Beograd, 2003, Izvodi radova, p. 80

66. Z. K. Jaćimović, Z. D. Tomić, G. Giester, V. S. Jevtović, V. M. Leovac, ICOSECS 4, Belgrade, 2004, Book of Abstracts, vol. I, p. 65

67. G. A. Bogdanović, V. S. Jevtović, V. M. Leovac, $7^{\text {th }}$ International Conference on Fundamental and Applied Aspects of Physical Chemistry, Belgrade, 2004, Proceedings, vol. II, p. 555

68. V. A. Kogan, V. V. Zelentsov, G. M. Larin, V. V. Lukov, Kompleksy perekhodnykh metallov s gidrazonami, Nauka, Moskva, 1990

69. N. S. Gupta, M. Mohan, N. K. Jha, W. E. Antholine, Iinorg. Chim. Acta 184 (1991) 13

70. S. B. Novaković, G. A. Bogdanović, V. S. Jevtović, V. M. Leovac, $10^{\text {th }}$ Conference of the Serbian Crystallographic Society, Sokobanja, 2002, Book of Abstracts, p. 25

71. T. S. Wang, Appl. Spectrosc. 22 (1968) 167

72. V. M. Kolb, J. W. Stupar, T. E. Janot,a W. L. Duax, J. Org. Chem. 54 (1989) 2341

73. V. Leovac, L. Bjelica, Lj. Jovanović, Polyhedron 4 (1985) 233

74. V. M. Leovac, Lj. S. Jovanović, L. J. Bjelica, V. I. Češljević, Polyhedron 8 (1989) 135

75. L. J. Bjelica, Lj. S. Jovanović, F. D. Gaál, Rev. Research, Chemistry Series, Faculty of Sciences, University of Novi Sad, 13 (1983) 37

76. Lj. S. Jovanović, N. J. Ević, L.J. Bjelica, F. F. Gaál, Microchem. J. 38 (1988) 343

77. Lj. S. Jovanović, N. J. Ević, L.J. Bjelica, F. F. Gaál, J. Serb. Chem. Soc. 55 (1990) 219

78. G. K. Budnikov, Elektrokhimicheskie reaktsii khelatov metallov v organicheskikh i smeshannykh rastvoritelyakh, Izd. Kazanskogo universiteta, 1980, pp 100-130 (in Russian)

79. M. Cañadas, E. López-Torres, A. Martínez-Arias, M. A. Mendíola, M. T. Sevilla, Polyllhedron 19 (2000) 2059

80. O. Manoušek, P.Zuman, J. Electroanal. Chem. 1 (1959/60) 324

81. T. Pineda, J. M. Sevilla, M. Blazquez, F. Garcia-Blanco, M. Dominguez, J. Electroanal. Chem. 304 (1991) 53

82. L. Bjelica, Lj. Jovanović, J. Electroanal. Chem. 213 (1986) 85

83. L. J. Bjelica, Lj. S. Jovanović, V. M. Leovac, Z. Phys. Chemie (Leipzig) 269 (1988) 768

84. G. Domagk, R. Behnisch, F. Mietzsch, H. Schmidt, Natturwissenschaften 33 (1946) 315

85. H. Beraldo, D. Gambino, Mini-Rev. Med. Chem. 4 (2004) 159

86. D. R. Richardson, Critical Reviews in Oncology/Hematology 42 (2002) 267

87. F. J. Giles, P. M. Fracasso, H. M. Kantarjian, J. E. Cortes, R. A. Brown, S. Verstovsek, Y. Alvarado, D. A. Thomas, S. Faderl, G. Garcia-Manero, L. P. Wright, T. Samson, A. Cahill, P. Lambert, W. Plunkett, M. Sznol, J. F. DiPersio, V. Gandhi, Leukemia Research 27 (2003) 1077

88. A. Y. Louie, T. J. Meade, Chem. Rev. 99 (1999) 2711

89. A. Singh, R. Dhakarey, G. C. Saxena, J. Indian Chem. Soc. 73 (1996) 339

90. R. J. Anderson, I. S. Cloudsdale, R. J. Lamoreaux, K. Schaefer, J. Harr, 2000: US Patent, 6.110.869

91. M. T. Cocco, A. Plumitallo, M.L. Schivo, A. Delogu, Farmaco 45 (1990) 1101

92. M. C. Cardia, M. Begala, A. Delogu, E. Maccioni, A. Plumitallo, Formaco 55 (2000) 93

93. M. T. Cocco, C. Congiu, V. Onnis, M. L. Pellerano, A. Delogu, Bioorg. Med. Chem. 10 (2002) 501

94. J. T. Edward, BioMetals. 11 (1998) 203

95. P. V. Bernhardt, P. Chin, D. R. Richardson, J.Biol. Inorg. Chem. 6 (2001) 801

96. G. Darnell, D. R. Richardson, Blood 94 (1999) 781 and refs. therein 
97. M. Baldini, M. Belicchi Ferrari, F. Bisceglie, G. Pelosi, S. Pinelli, P. Tarasconi, Inorg. Chem. 42 (2003) 2049

98. J. B. Ubbink, W. J. Serfontein, L. S. De Viliers, J. Chromat. B 342 (1985) 277

99. L. Ballesteros, D. Pérez-Bendito, Analyst 108 (1983) 443

100. M. Marquez, M. Silva, D. Pérez-Bendito, Anal. Chim. Acta 239 (1990) 221

101. E. Vereda, A. Rios, M. Valcarcel, Analyst 122 (1997) 85

102. E. Cristofol de Alcaraz, F. Sánchez Rojas, J. M. Cano Pavón, Fresenius' J. Anal. Chem. 340 (1991) 175

103. L. S. Sarma, G. N. Ramesh, C. J. Kumar, A. V. Reddy, J. Indian Chem. Soc. 77 (2000) 405 104. B. I. Ita, O. E. Offiong, Mat. Chem. Phys. 48 (1997) 164. 